\title{
EL CONCORDATO ENTRE LA SANTA SEDE Y EL GOBIERNO DE POLONIA DE 1925 COMO FUENTE DE LOS PROYECTOS DE CONCORDATO ENTRE CHILE Y LA SANTA SEDE DE 1928*
}

Sumario: -1 . Los proyectos de concordato entre Chile y la Santa Sede de 1928. - 1.1. La iniciativa para celebrar el concordato y sus fuentes. - 1.2. Los proyectos de concordato. - 2. El concordato entra la Santa Sede y Polonia de 1925 en los proyectos de concordato chilenos de 1928. - 2.1. Libertad de la Iglesia. - 2.2. Régimen tributario. - 2.3. Apoyo secular a decisiones eclesiásticas. - 2.4. Embago de sueldos de funcionarios eclesiásticos. - 2.5. Servicio militar de eclesiásticos. - 2.6. Exención de cargos incompatibles para los clérigos. - 2.7. Inmunidad de iglesias. - 2.8. Capellanes castrenses. - 2.9. Autoridad en Chile de obispos residentes fuera de Chile. -2.10 . Superiores extranjeros de comunidades religiosas masculinas. - 2.11. Juramento de los obispos. - 2.12. Actos administrativos estatales sobre bienes eclesiásticos. - 2.13. Adquisición de bienes por la Iglesia. - 2.14. Cementerios católicos. - 2.15. Fieles fuera de su diócesis. -2.16 . Obtención de beneficios parroquiales. - 2.17. Acusaciones contra eclesiásticos. - Conclusiones.

Chile, situado en el extremo sur de América Latina, obtuvo su independencia de la Corona española en 1818. Poco después, inició sus contactos con la Santa Sede producto de los cuales fue el envío de

\footnotetext{
* Esta investigación ha sido realizada con ocasión del Proyecto Fondecyt 1120345 del que su autor es investigador responsable. This research has been funded by Proyecto Fondecyt 1120345, and the author is the leading researcher.
} 
la primera misión diplomática enviada por la Santa Sede a los países hispanoamericanos recién independizados, encabezada por monseñor Giovanni Muzzi cuyo secretario era el joven monseñor Giovanni Maria dei conti Mastai Ferreti quien, con los años, con el nombre de Pio IX, conduciría el pontificado más largo de la historia (1846-1878)².

A lo largo del siglo XIX, por iniciativa del gobierno de Chile, hubo contactos con la Santa Sede con la finalidad de firmar un concordato, iniciativa en la que el gobierno de Chile no estuvo solo, pues otros países latinoamericanos pretendieron lo mismo; pero, si bien la Santa Sede firmó concordatos con algunos de estos países, con Chile no se llegó a un acuerdo formal ${ }^{3}$. El régimen de patronato, del que el gobierno de Chile se sentía heredero de las autoridades hispanas ${ }^{4}$ y que había consagrado formalmente en la Constitución Política de 1833, impidió firmar el proyectado concordato, no obstante la buena voluntad manifestada por la Santa Sede. Finalmente, la pretensión fue dejada de lado por las autoridades chilenas ${ }^{5}$.

En 1925 se sustituyó la casi centenaria Constitución de 1833 por la Constitución de 1925, en la cual se proclamó la libertad de cultos, poniendo fin al régimen de confesionalismo católico que había caracterizado al Chile republicano desde los inicios de su vida independiente. La separación entre la Iglesia y el Estado de Chile se produjo de manera amigable, después de conversaciones informales entre el

\footnotetext{
${ }^{2}$ L. Calm, El Chile de Pío IX: 1824 (Santiago, 1987).

${ }^{3}$ Firmaron concordato con la Santa Sede: Bolivia (1851), Costa Rica (1852), Guatemala (1852, 1884), Haití (1860), Honduras (1861), Nicaragua (1861), San Salvador (1862), Venezuela (1862), Ecuador (1862, 1881), Colombia (1887).

${ }^{4}$ El patronato fue concedido por en Papa Julio II (1503-1513) a los Reyes Católicos mediante la bula Universalis Ecclesiae Regiminis, de 28 de julio de 1508. La mejor edición es la de P. Leturia, La bula del patronato de las Indias españolas que falta en el Archivo Vaticano, en: P. Leturia, Relaciones entre la Santa Sede e Hispanoamérica, 1: Época del real patronato 1493-1880 (Caracas, 1959), pp. 253-258.

${ }^{5}$ C. Oviedo Cavada, Un siglo de relaciones entre la Santa Sede y Chile, 1822-1925, en: Diplomacia 39 (Santiago de Chile, 1987), pp. 18-30; Él mismo, Negociaciones chilenas sobre convenios con la Santa Sede, en: Finis Terrae 19 (Santiago de Chile, 1958), pp. 37-53; Él mismo, La misión Irarrázabal en Roma 1847-1850 (Santiago de Chile, 1962).
} 
presidente de entonces, Arturo Alessandri Palma, y el cardenal Pedro Gasparri, Secretario de Estado de Pío XI (1922-1939). Para convenir en dicha separación la Santa Sede puso algunas condiciones, una de las cuales era la firma de un concordato, pero el presidente Alessandri consideró que un documento de tal naturaleza requería un tiempo de preparación de que no disponía, por la urgencia que tenía para promulgar la nueva Constitución. Por lo demás, las otras condiciones estaban todas cumplidas en el nuevo texto constitucional ${ }^{6}$.

Poco se ha sabido acerca del pretendido concordato que debió celebrarse con ocasión de la Constitución de 1925, si bien no han faltado antecedentes ${ }^{7}$, algunos recientes ${ }^{8}$, que permitían pensar que había habido gestiones para formalizar el concordato que solicitaba la Santa Sede, a diferencia de los intentos decimonónicos en los que la iniciativa concordataria había surgido del Estado de Chile. La apertura del Archivo Secreto Vaticano en lo relativo a los fondos del pontificado de Pío XI decretada por el Papa Benedicto XVI ${ }^{9}$ ha venido a mostrar que, efectivamente, hubo conversaciones oficiales entre el gobierno y la Santa Sede tendentes a la conclusión de un concordato.

${ }^{6}$ Las condiciones eran: i) Chile no debía convertirse en Estado ateo y, por eso, habría de obtenerse la invocación del nombre de Dios en la promulgación de la nueva Constitución; ii) la libertad de enseñanza, para dar cabida a la educación particular y que, en ciertos tipos de enseñanza, se indicara su obligatoriedad, sin añadir la palabra "laica"; iii) derogación expresa de todos los abusos regalistas de la Constitución de 1833, como el patronato, el pase regio, etc.; iv) entre los pactos internacionales había de hacerse expresa mención de los concordatos; v) la celebración de un concordato y una compensación económica del Estado al suprimir el presupuesto del culto. C. Oviedo CAvada, La jerarquía eclesiástica y la separación de la Iglesia y el Estado en 1925, en: Boletín de la Academia Chilena de la Historia 89 (Santiago de Chile, 1975-1976), p. 28.

${ }^{7}$ A. Lira, Memorias (Santiago de Chile, 1950), pp. 168-183.

${ }^{8}$ J.I. González Errázuriz, El Estado de Chile ante la Iglesia católica. ¿Existió un concordato en 1925?, en: Ius Publicum 5 (Santiago de Chile, 2000), pp. 47-57.

${ }^{9}$ Bolletino della Sala Stampa della Santa Sede, 30 junio 2006 n 0340, en: www. vatican.va [consultado el 24 de mayo de 2011]. 


\section{Los proyectos de concordato entre Chile y la Santa Sede de 1928}

\subsection{La iniciativa para celebrar el concordato y sus fuentes}

Las iniciativas tendientes a firmar un concordato llevadas adelante durante el siglo diecinueve fueron del gobierno chileno. Ahora, en 1928, la iniciativa correspondió a la Santa Sede. El 2 de enero de 1928, presentó sus credenciales en Santiago de Chile el nuncio Ettore Felici ${ }^{10}$ quien, en un despacho fechado en Santiago, el 15 de marzo de ese mismo año, dirigido al cardenal Secretario de Estado le manifestaba que "conforme a las instrucciones que me fueron dadas antes de mi partida de Roma, no he faltado en reclamar discretamente la atención del gobierno sobre la oportunidad de un concordato"11. Agregaba el nuncio que las conversaciones que sobre la materia había tenido con diversos miembros del gabinete parecía que estaban dando resultado, al punto que el ministro de Relaciones Exteriores le había comunicado en la última audiencia que tenía redactado un proyecto de concordato del que, una vez que obtuviera la aprobación del presidente de la República, le enviaría una copia para conocer su parecer. Más aún, el mismo día el subsecretario de dicho ministerio, que había tenido oportunidad de leerlo, le había manifestado que "salvo ligeras modificaciones", el proyecto seguía el texto del concordato que, poco antes, en octubre del año anterior, se había concluido con Lituania ${ }^{12}$, "texto

\footnotetext{
${ }^{10}$ Pío XI lo eligió arzobispo titular de Corinto y nuncio apostólico en Chile el 6 de noviembre de 1927, siendo consagrado en Santiago de Chile, el 30 de diciembre de 1927. Presentó sus credenciales el 2 de enero de 1928 al presidente Carlos Ibáñez del Campo.

11 "Conformemente alle istruzioni datemi prima della mia partenza da Roma, non ho mancato di richiamare discretamente l'attenzione del Governo su la opportunità di un concordato". Archivio Segreto Vaticano (= ASV), Sacra Congregazione degli Affari Ecclesiastici Straordinari (= AES), Cile 1927-1928. Pos. 283-285 PO. Fasc. 47, fols. 21-22.

${ }^{12}$ Concordat entre le Saint-Siège et le Gouvernement de Lithuanie (27 septembre 1927), en: Enchiridion dei concordati. Due secoli di storia dei rapporti Chiesa-Stato (Bologna, 2003), pp. 698-711, nº 1386-1421. En adelante: Enchiridion.
} 
que me ha parecido bien dar a conocer al ministro, para animarlo a seguir el ejemplo de la joven república"13. A la luz de estas noticias que el nuncio en Chile la proporcionaba a su superior, quedaba claro: i) que desde su llegada a Chile había intentado animar a las autoridades chilenas a celebrar un concordato, el que estaba pendiente desde la promulgación de la Constitución de 1925; ii) que eso lo hacía en cumplimiento de instrucciones que había recibido en Roma antes de su partida; iii) que para facilitar la redacción de ese concordato por parte de las autoridades chilenas, les había hecho llegar el texto del concordato que en octubre de 1927 había celebrado la Santa Sede con Lituania, animando a las autoridades chilenas a seguir el ejemplo de esta joven república.

Ahora bien, el concordato con Lituania sigue de cerca el concordato que el 10 de febrero de 1925 había celebrado la Santa Sede con la República de Polonia ${ }^{14}$, concordato que también fue tenido a la vista por las autoridades chilenas, pues, como se verá, algunos de los artículos de los proyectos chilenos se alejan de su modelo lituano y se aproximan al concordato polaco, el que, en ocaciones, es copiado textualmente.

Este interés de la Santa Sede de celebrar un concordato con Chile hay que situarlo en lo que se ha denominado "la nueva era de concordatos"15. En efecto, al finalizar la primera Guerra Mundial el panorama geográfico europeo había quedado modificado con la aparición de nuevos Estados independientes y el cambio de las fronteras de otros, lo que dio origen a un nuevo impulso en la celebración de concordatos bajo el pontificado de Pío XI que, en más de una ocasión,

\footnotetext{
13 "Salvo leggere modificazioni, il testo del concordato testé concluso con la Lituania, testo que avevo creduto bene portare a conoscenza del ministro, per incoraggiarlo a seguire l'esempio della giovane repubblica". ASV, AES, Cile 1927-1928. Pos. 283-285 PO. Fasc. 47, fol. 26.

${ }^{14}$ Sollemnis Conventio inter Sanctam Sedem et Poloniae Rempublicam (10 februarii 1925), en Enchiridion, pp. 654-675, n 1282-1326.

${ }^{15}$ La expresión es de Yves de La Brière, que recoge R. Minnerath, L'Église catolique face aux États. Deux siècles de pratique concordataire 1801-2010 (Paris, 2012), p. 61.
} 
ha sido llamado el papa de los concordatos ${ }^{16}$. Otras circunstancias mostraron también esta necesidad ${ }^{17}$ : por de pronto, era preciso hacer presente la Iglesia en un mundo que había sufrido transformaciones profundas no solo materiales sino también espirituales; las circunstancias habían cambiado de forma tal la estructura de las antiguas y nuevas naciones que se hacía necesario un reajuste de las relaciones con la Iglesia. La guerra había puesto fin a la alianza entre trono y altar, lo que presentaba una ocasion propicia para terminar definitivamente con los privilegios del regalismo; y también había puesto fin al típico liberalismo decimonónico cerrado a una conciliación con la Iglesia y había dado paso a un liberalismo más pragmático, abierto a la conveniencia política de una representación diplomática ante la Santa Sede. Todo ello hacía necesario restablecer o crear los medios jurídicos que facilitaren el actuar de la Iglesia. De hecho, todos los países con los que se celebraron concordatos asumieron una doble obligación: no obstaculizar la libre actividad religiosa y garantizar el libre ejercicio de dicha actividad; incluso, en algunos casos, como Italia ${ }^{18}$, Polonia ${ }^{19}$ y Lituania ${ }^{20}$, los eclesiásticos eran objeto de una especial protección. Además es posible que influyera la decidida actitud de Benedicto

\footnotetext{
${ }^{16}$ G. Stella, Pio XI il Papa del concordati (Milano, 2009).

${ }^{17}$ Y. De LA Brière, Aspect général de la politique concordataire du pontificat de Pie XI, en: Institut Pie XI (ed.), Les concordats conclus sous le pontificat de Pie XI (Paris, 1930), pp. 38-56; Y. Chiron, Pio XI. Il papa dei Patti Lateranensi e dell'opposizione ai totalitarismi (Milano, 2006), pp. 175-177; A. Consoli, Il pontificato di Pio XI e la società civile. Alcune riflessioni sulla sua attività concordataria, en: A. BAUsolA (ed.), Il pontificato di Pío XI a cinquant'anni di distanza (Milano, 1991), pp. 55-83; J. Escudero Imbert, El difícil pontificado de Pío XI, en: J.I. Saranyana (ed.), Cien años de pontificado romano. De León XIII a Juan Pablo II (Pamplona, 1997), pp. 77-119, esp. 86-89.

${ }^{18}$ Concordato fra la Santa Sede e l'Italia (11 febbraio 1929), art. 4-8, en: Enchiridion, pp. 747-748, no 1492-1496.

${ }^{19}$ Sollemnis Conventio inter Sanctam Sedem et Poloniae Rempublicam (10 februarii 1925), art. II, V, XVIII, XX, XXII, ibid., pp. 654-671, nº 1284, 1287, 1300, 1302, 1304.

${ }^{20}$ Concordat entre le Saint-Siège et le Gouvernement de Lithuanie (27 septembre 1927), art. II, V, XIV, XVIII, XX, XXIV, ibid., pp. 698-711, nº 1388, 1391, 1404, 1408, $1410,1417$.
} 
XV (1914-1922) en favor de una paz justa, que produjo un considerable aumento del prestigio público de la Iglesia ${ }^{21}$. Y, por su parte, los amplios movimientos revolucionarios del periodo de entreguerras impulsaron a muchos gobernantes a intentar un contrapeso con una aproximación a Roma. En total fueron 23 los convenios, concordatos y tratados firmados durante su pontificado, no solo con naciones de mayoría católica -Italia, Polonia-, sino también protestantes -Prusia $^{22}$ - y cismáticas - Rumania ${ }^{23}$-, destacando los Pactos de Letrán y los concordatos con el III Reich ${ }^{24}$ y con Austria ${ }^{25}$.

La "nueva era de los concordatos" se inició en 1922 con el concordato con el gobierno de Letonia, firmado el 30 de mayo de ese año ${ }^{26}$. Un nuevo concordato fue celebrado en 1924 entre la Santa Sede y el Estado de Baviera ${ }^{27}$ y, al año siguiente, con la República de Polonia, el 10 de febrero de $1925^{28}$. En 1927 fueron dos concordatos y un modus vivendi los celebrados por la Santa Sede: el primero de los concordatos fue celebrado con el Reino de Rumanía, el 10 de mayo de $1927^{29}$ y el 27 de septiembre de 1927 se celebró el concordato entre la Santa Sede

${ }^{21}$ G. Rumi, Benedetto XV e la pace, 1918 (Brescia, 1990); G. Rossini (ed.), Benedetto $X V$, i cattolici e la prima guerra mondiale (Roma, 1963).

${ }^{22}$ Vertrag des Freistaates Preussen mit dem Heiligen Stuhle (14 juni 1929), en: Enchiridion, pp. 752-773, n 1552-1597.

${ }^{23}$ Inter Sanctam Sedem et Romaniae Regnum Sollemnis Conventio (10 maii 1927), ibíd., pp. 680-699, nº 1336-1385.

${ }^{24}$ Konkordat zwischen dem Heiligen Stuhl und dem Deutschen Reich (20. Juli 1933), ibid., pp. 864-887, nº 1901-1951; V. ConZemius, Le concordat du 20 juillet 1933 entre le Saint-Siège et l'Allemagne. Esquisse d'un bilan de la recherche catholique, en Archivum Historiae Pontificae 6 (1977), pp. 333-362.

${ }^{25}$ Konkordat zwischen dem Heiligen Stuhl und der Republik Österreich (5. Juni 1933), en: Enchiridion, pp. 834-865, nº 1822-1900.

${ }^{26}$ Concordat entre le Saint-Siège et le Gouvernement de Lettonie (30 mai 1922), ibíd., pp. 590-597, n 1147-1171.

${ }^{27}$ Sollemnis conventio inter Sanctan Sedem et Bavariae Rempublicam (29 martii 1924), ibíd., pp 626-643, n 2016-1255.

${ }^{28}$ Sollemnis conventio inter Sanctam Sedem et Poloniae Rempublicam (10 februarii 1925), ibíd., pp. 654-675, n 1282-1326.

${ }^{29}$ Inter Sanctan Sedem et Romaniae Regnum Sollemnis Conventio (10 mai 1927), ibíd., pp. 680-699, nº 1336-1385. 
y el Gobierno de Lituania ${ }^{30}$. Además de los dos concordatos anteriores, el mismo año 1927, el 17 de diciembre, la Santa Sede firmó un modus vivendi con la República Checoslovaca ${ }^{31}$. No fueron los únicos acuerdos internacionales celebrados por la Santa Sede en los primeros años del pontificado de Pío XI que son, al mismo tiempo, los años inmediatamente anteriores a la redacción de los proyectos chilenos, pero no se trataron propiamente de concordatos ${ }^{32}$.

\subsection{Los proyectos de concordato}

Tres fueron los proyectos que en dicha ocasión se consideraron: dos de ellos presentados informalmente por el gobierno de Chile a consideración de la Santa Sede, lo que ocurrió en mayo de 1928; y el tercero, un contraproyecto presentado también informalmente por el nuncio apostólico en Chile a partir del segundo de los proyectos presentados por el gobierno chileno.

a) primer proyecto

El martes 1 de mayo de 1928, el embajador de Chile ante la Santa Sede hizo entrega en el Vaticano de un proyecto de concordato,

${ }^{30}$ Concordat entre le Saint-Siège et le Gouvernement de Lithuanie (27 septembre 1927), ibíd., pp. 698-711, no 1386-1422.

${ }^{31}$ Modus vivendi inter Sanctam Sedem et Rempublicam Cecoslovacham (17 desembris 1927), ibíd., pp. 710-715, nº 1423-1430.

${ }^{32}$ A los anteriores hay que agregar el intercambio de notas y la convención con Colombia para la interpretación del artículo 17 del concordato de 1887 (1923-1924) que para este estudio no tiene ninguna relevancia. El intercambio de notas entre la Secretaría de Estado y el Consejo de Estado del Cantón de Friburgo, en Suiza (1924). Los acuerdos entre la Santa Sede y Francia acerca de los honores litúrgicos en los países donde se ejerce el protectorado religioso francés o en los países donde las capitulaciones están abrogadas o no se aplican (1926), que en nada interesan a este estudio. Y el acuerdo entre la Santa Sede y el Gobierno de Portugal para actualizar algunos aspectos del concordato de 1886 (1928), que se firmaba el 15 de abril de 1928, es decir, pocos días antes de la presentación de los proyectos chilenos, ninguno de los cuales interesa a este estudio ya por lo específico de las materias reguladas, ya porque es muy probable que su texto, como el portugués, no hubiese sido conocido en Chile al tiempo de la redacción de sus proyectos. 
diciendo que tenía instrucciones de pedir el parecer de la Secretaría de Estado y que regresaría el viernes siguiente a recibir la respuesta. Así quedó consignado en un pro-memoria redactado al día siguiente, el 2 de mayo, por el cardenal Secretario de Estado, texto en el que se agregaba que dicho Secretario de Estado había examinado el concordato y había hecho relación de él al Santo Padre. A este texto, el primero de los tres elaborados, lo denominaré Proyecto ${ }^{33}$. En él llaman la atención las pretensiones neo-regalistas del gobierno de Chile que buscaba, ahora por la vía de un acuerdo internacional, recuperar parte de las atribuciones que, en relación con la Iglesia, había perdido como consecuencia de la separación Iglesia-Estado operada por la Constitución de 1925.

b) segundo proyecto

En despacho enviado por el nuncio al cardenal secretario de Estado el miércoles 30 de mayo de $1928^{34}$, le comunicaba que, en audiencia que le había concedido el ministro de Relaciones Exteriores al nuncio el miércoles anterior, 23 de mayo, le había hecho entrega del esperado proyecto de concordato; al mismo tiempo, el ministro le había pedido que lo examinara y le había solicitado que se lo restituyera lo más pronto, acompañado de sus observaciones. Este proyecto, que denominaré el Proyecto II, constaba de 27 artículos, dos artículos menos que el Proyecto I y en él se acentuaban las pretensiones neo-regalistas del gobierno manifestadas en el Proyecto I.

c) el contra-proyecto del nuncio

Cuando el ministro de Relaciones Exteriores entregó informalmente al nuncio el Proyecto II y le pidió que le hiciera llegar sus observaciones, el embajador papal le respondió que no podía entrar ni directa ni indirectamente en negociaciones, estando autorizado sólo

\footnotetext{
${ }^{33}$ C. Salinas Araneda, Un primer proyecto de concordato entre Chile y la Santa Sede en 1928, en: Revista Chilena de Derecho 39 (Santiago de Chile, 2012), pp. 665-698.

${ }^{34}$ ASV. AES. Cile 1927-1928. Pos. 283-285 PO. Fasc. 47. pp. 43-46.
} 
para recibir el proyecto a efectos de transmitirlo a Roma. Como el ministro insistiera en su deseo de conocer el parecer del nuncio antes de hacer entrega oficial del documento, el nuncio, temiendo alterar la buena disposición del secretario de Estado, consideró oportuno acceder a su petición, después de haberle hecho presente: i) que sus observaciones tendrían sólo el carácter de una consulta estrictamente personal; ii) que las opiniones expresadas por el nuncio no implicaban en modo alguno a la Santa Sede; iii) que la eventual tratativa entre el Vaticano y la Moneda se desarrollarían como si el nuncio no hubiese intervenido en el asunto ${ }^{35}$.

Con dichas reservas el nuncio aceptó el proyecto, examinándolo rápidamente la misma tarde, advirtiendo con sorpresa, que "lejos de respetar los derechos y la libertad de la Iglesia, contenía cláusulas peligrosas y disposiciones absolutamente inaceptables" ${ }^{36}$, de manera que "todo sumado el gobierno se aseguraría notables ventajas y la Iglesia vendría a encontrarse en una condición peor que la actual" ${ }^{37}$. Es por lo que, valiéndose de la libertad que le confería el carácter de consultor privado del gobierno, el nuncio modificó "sin piedad" -las palabras son suyas- el proyecto y lo restituyó al ministro junto al texto primitivo. El mismo día tuvo una larga conversación con el subsecretario, a quien explicó detalladamente los cambios introducidos a efectos de que él pudiese, a su vez, justificarlos y defenderlos ante el canciller.

El contraproyecto presentado por el nuncio, que denominaré Proyecto III, está distribuido en el mismo número de artículos que el Proyecto II, esto es, 27 artículos, pero no significó una mera repetición corregida de este último, pues hubo artículos de éste que fueron eliminados, se agregaron otros y la mayoría restante sufrió algunas modificaciones en su redacción, permaneciendo sin cambio alguno sólo ocho de los 27 artículos originales. Del análisis del nuevo

\footnotetext{
${ }^{35}$ ASV. AES. Cile 1927-1928. Pos. 283-285 PO. Fasc. 47. pp. 43-44.

36 "[...] lungi dal rispettare i diritti e la libertá della Chiesa, conteneva clausole pericolose e disposizioni assolutamente inaccettabili”. Ibíd.

37 "Tutto sommato il Governo si assicurerebbe notevoli vantaggi e la Chiesa verrebbe a trovarsi in una condizione peggiore della attuale”. Ibíd.
} 
articulado aparece que el interés del nuncio fue doble: por una parte, afirmar la personalidad jurídica de derecho público de la Iglesia y de sus entes; y, por otra, disminuir los excesos neo-regalistas del Proyecto II, pero sólo disminuir, pues permanecieron en el contraproyecto del nuncio algunos resabios regalistas, como el juramento de los obispos.

De los tres proyectos redactado en 1928, me interesan los dos primeros, redactados ambos por el gobierno de Chile. Como el segundo es una revisión reformada del primero, las consideraciones que siguen las hago a partir del segundo de los proyectos gubernamentales chilenos.

\section{El concordato entra la Santa Sede y Polonia de 1925 en los proyectos de concordato chilenos de 1928}

\subsection{Libertad de la Iglesia}

Según el artículo 1 de los proyectos del gobierno chileno, "La Iglesia Católica gozará en el territorio de la República de Chile de plena libertad y podrá erigir y conservar templos y sus dependencias con las condiciones de seguridad e higiene fijadas por las leyes y ordenanzas que rigen en Chile sobre la materia". Se trataba de un artículo introductorio, en el que se hacía una declaración de principios que mira a un aspecto de la libertad de la Iglesia en orden a su actuar, cual es el de la erección y conservación de templos y sus dependencias. No es una declaración general de reconocimiento de libertad, sino parcial $\mathrm{y}$, por lo mismo, se ve complementada con el artículo siguiente que vuelve sobre la libertad de la Iglesia, pero en perspectiva diversa.

Se trata de una norma que, con diversas fórmulas, se encuentra en los concordatos celebrados en estos años, en concreto Letonia (1922, 
art. ${ }^{38}$ ), Baviera (1924, art. $\left.1^{39}\right)$, Rumanía $\left(1927\right.$, art. $\mathrm{I}^{40}$ ) y Lituania (1927, art. $1^{41}$ ), si bien la fórmula que parece utilizada como inspiradora de este artículo y del artículo 2 que sigue, es la que se encuentra en el concordato celebrado con Polonia en 1925 (art. $\mathrm{I}^{42}$ ), en el que

${ }^{38}$ Concordat entre le Saint-Siège et le Gouvernement de Lettonie (30 mai 1922), art. I: "La religión catholique será librement et publiquement exercée en Lettonie et la personnalité juridique avec tous les droits, que le Code Civil de Lettonie reconnaît aux autres personnes civiles, lui será reconnue" = "La religión católica será libremente y públicamente ejercida en Letonia y le será reconocida la personalidad jurídica con todos los derechos que el Código Civil de Letonia reconoce a las otras personas civiles", en: Enchiridion, p. 590, no 1148 .

${ }^{39}$ Sollemnis conventio inter Sanctan Sedem et Bavariae Rempublicam (29 martii 1924), art. 1: “\$1. Der Bayerische Staat gewährleistet die freie und öffentliche Ausübung der katholischen Religion. $\$ 2$. Er anerkennt das Recht der Kirche, im Rahmen ihrer Zuständigkeit Gesetze zu erlassen und anordnungen zu treffen, die ihre Mitglieder binden; er wird die Ausübung dieses Rechtes weder hindern noch erschweren. \$3. Er sichert der katholischen Kirche die ungestörte Kultübung zi. In der Erfülhung ihrer Amtspflichten geniessen die Geitlichen den Schutz des Staates" = "\$1. El Estado de Baviera garantiza el libre y público ejercicio de la religión católica. $\$ 2$. Reconoce el derecho de la Iglesia de emanar en el ámbito de su competencia leyes y decretos, que obligan a sus miembros; y no impedirá ni volverá difícil el ejercicio de este derecho. $\$$ 3. Asegura a la Iglesia católica el ejercicio tranquilo del culto. En los actos de su oficio los eclesiásticos gozan de la protección del Estado", ibíd., p. 628, n 1207-1209.

${ }^{40}$ Inter Sanctan Sedem et Romaniae Regnum Sollemnis Conventio (10 mai 1927), art. I: "La Religion Catholique Apostolique Romaine, de tout rite, será pratiquée et exercée librement et publiquement dans tout le Royaume de Roumanie" = "La religión Católica Apostólica Romana, de todo rito, será practicada y ejercida libremente y públicamente en todo el reino de Rumanía”, ibíd., p. 680, nº 1337.

${ }^{41}$ Concordat entre le Saint-Siège et le Gouvernement de Lithuanie (27 septembre 1927), art. I: "L'Eglise Catholique, sans distinction de Rites, jouira dans la République de Lithuanie de toutes les libertés nécessaires à l'exercice de son pouvoir spirituel et de sa juridiction ecclésiastique, ainsi qu'a l'administration et gestión de ses affaires et de ses biens, conformément aux Lois divines et au Droit Canon" = "La Iglesia Católica, sin distinción de ritos, gozará en la República de Lituania de todas las libertades necesarias para el ejercicio de su poder espiritual y de su jurisdicción eclesiástica, así como para la administración y gestión de sus asuntos y de sus bienes, conforme a las leyes divinas y al derecho canónico", ibíd., p. 698, n 1387.

${ }^{42}$ Sollemnis conventio inter Sanctam Sedem et Poloniae Rempublicam (10 februarii 1925), art. I: “'L'Eglise Catholique, sans distinction de Rites, jouira dans la République 
se inspiraba el concordato con Lituania, si bien el proyecto chileno introducía un cambio importante.

En efecto, según el artículo 2 del proyecto chileno, el libre actuar de la Iglesia se hacía "conforme al derecho canónico en cuanto no se oponga a las leyes chilenas". Se trataba de un cambio de redacción que otorgaba una preeminencia al derecho chileno por sobre el derecho canónico, cambio que hay que situar en la nueva actitud que el gobierno de Chile empezaba a tener hacia la Iglesia, tratando de recuperar, con un verdadero espíritu neo-regalista, una influencia sobre la Iglesia que había perdido al proclamar constitucionalmente la separación entre la Iglesia y el Estado. En cambio, el reconocimiento de la libertad de la Iglesia que se formulaba en los concordatos vigentes, se hacía con referencia a la leyes divinas y al derecho canónico, pero nada se decía en cuanto al derecho de cada uno de los estados firmantes; en este aspecto, es evidente que el proyecto chileno se alejaba del concordato polaco. La referencia al derecho canónico "en cuanto no se oponga a las leyes chilenas" sólo se explica por ese espíritu de neo-regalismo que aparece más manifiesto en otros artículos de este proyecto, como veremos.

\subsection{Régimen tributario}

En un extenso artículo 3 del proyecto se disponía que "Los eclesiásticos, sus bienes y los de las iglesias, ordinarios, parroquias y comunidades religiosas quedan sometidos a impuestos del mismo modo que las personas y los bienes de los ciudadanos de la República y que las personas jurídicas laicas, pero estarán exentos de contribuciones los templos y sus dependencias, destinados al servicio del culto católico,

de Pologne d'une pleine liberté. L'Etat garantit à l'Eglise le libre exercice de son pouvoir spirituel et de sa juridiction ecclésiastique, de même que la libre administration et gestión de ses affaires et de ses biens, conformément aux Lois divines et au Droit Canon" = "La Iglesia Católica, sin distinción de ritos, gozará en la República de Polonia de plena libertad. El Estado garantiza a la Iglesia el libre ejercicio de su poder espiritual y de su jurisdicción eclesiástica, así como la libre administración y gestión de sus asuntos y de sus bienes, conforme a las leyes divinas y al derecho canónico", ibíd., pp. 654, n 1283 . 
las casas parroquiales y de residencia de los ordinarios, los hospitales, hospicios, orfelinatos y, en general, los locales de instituciones católicas destinadas a dar auxilio o habitación gratuita a los desvalidos, en la parte afecta a tales servicios y siempre que ninguna porción de su renta sea destinada a fines de lucro personal y los locales de los seminarios, universidades, escuelas y colegios católicos en las partes afectas a servicios de instrucción y que no produzcan rentas". Se repetía, en parte, lo que decía la Constitución Política de 1925, según la cual “los templos y sus dependencias, destinados al servicio de un culto, estarán exentos de contribuciones" (art. $10 \mathrm{n}^{\circ} 2$ inc. $3^{\circ}$ ). Tenía el mérito, sin embargo, de especificar algunas situaciones que según el texto constitucional eran poco claras, como la situación de las casas parroquiales y de la residencia de los ordinarios.

En el concordato con Letonia ${ }^{43}$ se disponía que las propiedades de la Iglesia podrían quedar sometidas a impuesto, al igual que los bienes de los otros ciudadanos, con excepción de los edificios destinados al culto divino, así como los seminarios, y obispados y los presbiterios. Más extenso era en esta materia el concordato con Polonia que, al menos en parte, parece haber servido nuevamente de modelo al proyecto chileno, en el que se disponía que "los eclesiásticos, y sus bienes y los bienes de las personas jurídicas eclesiásticas y religiosas, son imponibles al igual que las personas y los bienes de los ciudadanos de la República y de las personas jurídicas laicas, con la excepción, sin embargo, de los edificios consagrados al servicio divino, de seminarios eclesiásticos, de casas de formación de religiosos y religiosas, así como de las casas habitación de religiosos y religiosas que han hecho voto de pobreza, y de los bienes y títulos cuyas rentas son destinadas a las necesidades del culto religioso y no contribuyan a las rentas personales de los beneficiarios. Las habitaciones de los obispos y del clero parroquial, así como sus locales oficiales, serán tratados por el fisco al igual

\footnotetext{
${ }^{43}$ Concordat entre le Saint-Siège et le Gouvernement de Lettonie (30 mai 1922), art. XVI: “Les propriétés de l'Eglise pourront être soumises aux impôts, comme les biens des autres citoyens, excepté les édifices destinés au culte divin, ainsi que le séminaire, les évêchés et les presbytères", ibíd., p. 594, nº 1163.
} 
que las habitaciones oficiales de los funcionarios y de los locales de las instituciones del Estado" "44. Un contenido idéntico ofrece el concordato con Lituania ${ }^{45}$, que sigue textualmente al concordato polaco. El proyecto chileno, sin embargo, dejaba fuera de la exención tributaria los conventos y monsaterios.

\subsection{Apoyo secular a decisiones eclesiásticas}

Según el artículo 5, "Las autoridades chilenas apoyarán la ejecución de las decisiones y de los decretos eclesiásticos en caso de prohibición a un eclesiástico del ejercicio del ministerio sacerdotal en locales públicos destinados al culto o del uso del hábito eclesiástico que sea actualmente usado por el clero secular o regular católico, de resguardo del orden en actos o manifestaciones religiosas en lugares públicos y en las otras circunstancias en que prescriban o permitan tal apoyo las leyes chilenas”. El artículo regulaba dos situaciones diversas. La primera,

\footnotetext{
${ }^{44}$ Sollemnis conventio inter Sanctam Sedem et Poloniae Rempublicam (10 februarii 1925), art. XV: “Les ecclésiastiques, leurs biens et les biens des personnes juridiques ecclésiastiques et religieuses, sont imposables à l'égal des personnes et des biens des citoyens de la République et des personnes juridiques lä̈ques, à l'exception toutefois des édifices consacrés au service divin, des séminaires ecclésiastiques, des maisons de formation des religieux et religieuses, de même que des maisons d'habitation des religieux et religieuses qui ont fait voeu de pauvreté, et des biens et titres dont les revenus sont destinés aux besoins du culte religieux et ne contribuent pas aux revenus personnels des bénéficiaires. Les habitations des Evêques et du clergé paroissial, de même que leurs locaux officiels, seront traités par le Fisc à l'égal des habitations officielles des fonctionnaires et des locaux des Institutions de l'Etat", ibíd., p. 662, nº 1297.

${ }^{45}$ Concordat entre le Saint-Siège et le Gouvernement de Lithuanie (27 septembre 1927), art. XVI: "Les ecclésiastiques, leurs biens et les biens des personnes juridiques ecclésiastiques et religieuses, sont imposables à l'égal des personnes et des biens des citoyens de la République et des personnes juridiques laïques, à l'exception toutefois des édifices consacrés au service divin, des séminaires ecclésiastiques, des maisons de formation des religieux et religieuses, de même que des maisons d'habitation des religieux et religieuses qui ont fait voeu de pauvreté, et des biens et titres dont les revenus sont destinés aux besoins du culte religieux et ne contribuent pas aux revenus personnels des bénéficiaires. Les habitations des evêques et du clergé paroissial, de même que leurs locaux officiels, seront traités par le Fisc à l'égal des habitations officielles des fonctionnaires et des locaux des Institutions de l'Etat", ibíd., p. 704, nº 1406.
} 
es la del apoyo a las decisiones y decretos de la autoridad eclesiástica que han sancionado a un eclesiástico: i) con la prohibición del ejercicio del ministerio sacerdotal en locales públicos destinados al culto, o ii) con la prohibición del uso del hábito eclesiástico actualmente usado por el clero secular o regular. Nos encontramos nuevamente con un artículo en que se proyecta la vieja tradición patronatista del apoyo del brazo secular a la Iglesia, sólo que, ahora, se trataba de una posibilidad que no cabía en un régimen de separación entre ambos poderes como ocurría en Chile a partir de 1925. En todo caso, se trataba de un auxilio a la Iglesia, no de una carga.

La segunda parte del artículo no agregaba nada a lo ya existente, porque tan solo se explicitaba una tarea del Estado que, con este artículo o sin él, realizaba y seguiría realizando cuando había actos o manifestaciones religiosas en lugares públicos: resguardar el orden en ellos. Lo actuado a este respecto en los años siguientes a la separación Iglesia-Estado es una prueba evidente de ello.

El único concordato de los contemporáneo a este proyecto en el que se contemplaba una norma similar era el concordato con Polonia $(1925)^{46}$, al que siguió de cerca el concordato con Lituania $(1927)^{47}$.

${ }^{46}$ Sollemnis conventio inter Sanctam Sedem et Poloniae Rempublicam (10 februarii 1925), art. IV: “Les autorités civiles prêteront leur appui à l'execution des décisions et des décrets ecclésiastiques: a) au cas de destitution d'un ecclésiastique, de sa privation d'un bénéfice de l'Eglise, après promulgation d'un décret canonique relatif à la destitution ou privation susmentionnées, ou cas défense du port de l'habit ecclésiastique; b) au cas de perceptions de taxes ou prestations destinées à des buts ecclésiastiques et prévues par les lois de l'Etat; c) dans tous les autres cas prévues par les lois en vigueur" = "Las autoridades civiles prestarán su apoyo a la ejecución de las decisiones y decretos eclesiásticos: a) en el caso de destitución de un eclesiástico, de su privación de un beneficio de la Iglesia, después de la promulgación de un decreto canónico relativo a la destitución o privación antes mencionada, o en el caso de prohibición de llevar hábito eclesiástico; b) en el caso de percepción de tasas o prestaciones destinadas a fines eclesiásticos y previstas por las leyes del Estado; c) en todos los otros casos previstos por las leyes en vigor", ibíd., p. 656, n 1286.

${ }^{47}$ Concordat entre le Saint-Siège et le Gouvernement de Lithuanie (27 septembre 1927), art. IV: “Les autorités civiles prêteront leur appui à l'execution des décisions et des décrets ecclésiastiques: au cas de destitution d'un ecclésiastique ou de sa privation 
Me parece que la norma del concordato con Polonia fue la tenida a la vista por las autoridades del gobierno chileno, pues elementos de dicha norma concordataria están presentes en la formulación de este artículo. Sin embargo, la norma concordada con Polonia era más compleja y sólo se refería a la primera parte del artículo del gobierno chileno.

\subsection{Embargo de sueldos de funcionarios eclesiásticos}

Disponía el artículo 6 de los proyectos chilenos, "Se aplicará a los sueldos, gratificaciones y pensiones, que percibieren los funcionarios eclesiásticos como tales las disposiciones legales que estén en vigor sobre embargo de sueldos, gratificaciones y pensiones que pagan el Estado y las municipalidades". Se trata de un artículo que abordaba una materia contenida en algunos de los concordatos contemporáneos, en concreto, el concordato de Lituania ${ }^{48}$, el que, a su vez, se basaba en el concordato con Polonia, cuyo artículo IV se refiere a esta materia ${ }^{49}$, regulándola

d'un bénéfice ecclésiastique; ou cas défense du port de l'habit ecclésiastique; au cas de perceptions de taxes, destinées à des buts ecclésiastiques et permises par les lois de l'Etat" = "Las autoridades civiles prestarán su apoyo a la ejecución de las decisiones $y$ decretos eclesiásticos: en el caso de destitución de un eclesiástico o de su privación de un beneficio eclesiástico; en el caso de prohibición de llevar hábito eclesiástico; en el caso de percepción de tasas, destinadas a fines eclesiásticos y permitidas por las leyes del Estado", ibid., p. 700, n 1390.

${ }^{48}$ Concordat entre le Saint-Siège et le Gouvernement de Lithuanie (27 septembre 1927), art. V inc. 10: "Les ecclésiastiques jouiront dans l'éxercice de leur ministère d'une protection juridique spéciale. A l'égal des fonctionnaires de l'Etat, ils bénéficieront du droit d'exemption de la saisie judiciaire pour une partie de leurs traitements". Véase la traducción en la nota siguiente.

${ }^{49}$ Sollemnis conventio inter Sanctam Sedem et Poloniae Rempublicam (10 februarii 1925), art. V: “Les ecclésiastiques jouiront dans l'éxercice de leur ministère d'une protection juridique spéciale. A l'égal des fonctionnaires de l'Etat, ils bénéficieront du droit d'exemption de la saisie judiciaire pour une partie de leurs traitements. Les eclésiastiques ayant reçu les ordres, les religieux ayant prononcé leurs voeux, les élèves des seminaires et les novices, qui se seraient présentés aux seminaires et aux noviciats avant une déclaration de guerre, seront exemptés du service militaire, excepté les cas de levée en masse. Dan ces derniers cas les prêtres ordonnés exerceront dans l'armée leur ministère, sans qu'il soit porté pérjudice, cependant, aux intérêts des paroisses, tandis 
junto a otras dos que también serían contempladas en el proyecto chileno, pero en artículos diversos. En este sentido, se sigue en Chile más de cerca el modelo lituano de tratar estas materias por separado.

\subsection{Servicio militar de eclesiásticos}

Artículo 7 del proyecto chileno disponía que "Los eclesiásticos que ya hubieren sido ordenados, los religiosos que ya hubieren hecho votos, los alumnos de los seminarios de la sección eclesiástica y los novicios que hubieren ingresado a los seminarios o noviciados antes de una declaración de guerra, estarán exentos del servicio militar obligatorio, exceptuando el caso de reclutamiento general. En este último caso y cuando se enrolaren voluntariamente, los miembros del clero y religiosos, especialmente los sacerdotes ordenados, serán destinados de preferencia a ejercer su ministerio en las filas o a los servicios sanitarios o de administración". La fuente del mismo me parece que hay que buscarla más en el concordato con Polonia que en el artículo V inc. $2^{\circ}$ del concordato con Lituania ${ }^{50}$,

que les autres membres du clergé seront affectés au service sanitaire. Les ecclésiastiques seront libérés des fonctions civiques, incompatibles avec la vocation sacerdotale, telles que celles de jurés, des membres des tribunaux, etc. = Los eclesiásticos gozarán en el ejercicio de su ministerio de una protección jurídica especial. Al igual que los funcionarios del Estado, ellos se beneficiarán del derecho de exención del embargo judicial para una parte de sus estipendios. Los eclesiásticos que hayan recibido las órdenes, los religiosos que hayan pronunciado sus votos, los alumnos de los seminarios y los novicios, que se encuentren presentes en los seminarios y noviciados antes de una declaración de guerra, estarán exentos del servicio militar, excepto en los casos de leva en masa. En estos últimos casos los sacerdotes ordenados ejércerán en el ejercito su ministerio, sin que ello signifique perjuicio, sin embargo, a los intereses de las parroquias, mientras que los otros miembros del clero serán afectados a los servicios sanitarios. Los eclesiásticos estarán liberados de las funciones cívicas incompatibles con la vocación sacerdotal, tales como las de jurado, miembros de tribunales, etc.", ibíd., p. 656, nº 1287.

${ }^{50}$ Concordat entre le Saint-Siège et le Gouvernement de Lithuanie (27 septembre 1927), art. V inc. 2: "Les eclésiastiques ayant reçu les ordres, les religieux ayant prononcé leurs voeux, les élèves des seminaires et les novices dans les noviciats, s'ils persévèrent dans leur état ecclesiastique ou religieux, seront exemptés du service militaire, même dans le cas de guerre et de levée en masse. Les ecclésiastiques seront aussi libérés des fonctions civiques, incompatibles avec la vocation sacerdotale selon de droit canon" = "Los eclesiásticos que hayan recibido las órdenes, los religiosos 
-también se encontraba en el concordato con Letonia ${ }^{51}$ - si bien, seguía al de Lituania en cuanto le daba a esta materia un tratamiento autónomo respecto del embargo de los sueldos de los eclesiásticos, optando por regular la materia en un artículo distinto y único, separándose en esto también del modelo lituano que lo hacía en un mismo artículo, pero en dos incisos separados. Sin embargo, el concordato lituano era en este punto claramente favorable a la Iglesia, otorgándole más beneficios a los eclesiásticos que el mismo concordato polaco que fue el modelo que siguió Chile. Pero, incluso, si bien siguió al concordato polaco, que es algo mas exigente que el lituano, todavía el artículo chileno es más estricto, pues introducía un matiz que no estaba en los modelos tenidos a la vista, cuando decía que "los miembros del clero y religiosos, especialmente los sacerdotes ordenados, serán destinados de p refe re n c i a a ejercer su ministerio en las filas o a los servicios sanitarios o de administración"; al introducir la expresión "de preferencia" no excluía que se les enviare directamente al servicio de las armas. Con ello este artículo superaba a sus modelos y volvía a proyectarse el neo-regalismo del gobierno, dejando establecida, si bien a modo de excepción, un nuevo gravamen del Estado sobre la Iglesia.

2.6. Exención de cargos incompatibles para los clérigos

Según el artículo 8 "Los eclesiásticos estarán exentos de ejercer funciones o encargos incompatibles con el ministerio sacerdotal, como el de administrar justicia en asuntos ajenos al fuero eclesiástico". Se trataba de una materia importante para la Iglesia y por lo mismo se encontraba en los concordatos contemporáneos a este proyecto, siendo los celebrados con Polonia ${ }^{52}$ y Lituania ${ }^{53}$ los que han servido de modelo, si bien se

que hayan pronunciado sus votos, los alumnos de los seminarios y los novicios en los noviciados, si ellos perseveran en su estado eclesiástico o religioso, estarán exentos del servicio militar, incluso en caso de guerra y de leva en masa. Los eclesiásticos estarán también liberados de las funciones cívicas incompatibles con la vocación sacerdotal según el derecho canónico", ibid., p. 700, nº 1391.

${ }^{51}$ Véase más adelante nota 54.

${ }^{52}$ Véase antes nota 49.

${ }^{53}$ Véase antes nota 50. 
redactaba la misma idea de manera diversa en el proyecto chileno. Una cláusula similar se encontraba en el concordato con Letonia, en el que, en una misma norma, se regulaba el servicio militar de los eclesiásticos y las funciones cívicas incompatibles, proporcionando el mismo ejemplo de miembro de los tribunales de justicia ${ }^{54}$.

\subsection{Inmunidad de iglesias}

El artículo 9 del proyecto chileno disponía que "El Gobierno de Chile asegura la inmunidad de las iglesias, capillas, conventos y cementerios católicos hasta donde la permitan el respeto de la ley chilena y las exigencias de la seguridad pública". Se trataba nuevamente de una materia que se encontraba en los concordatos de la época, como el de Letonia $(1922)^{55}$, Polonia $(1925)^{56}$ y Lituania $(1927)^{57}$, regulada en un artículo único, modelo que siguió Chile, pero ampliando los lugares beneficiados con la inmunidad, pues, a las iglesias, capillas y cementerios, agregaba los conventos, que no aparecían en dichos

${ }^{54}$ Concordat entre le Saint-Siège et le Gouvernement de Lettonie (30 mai 1922), art. IX: "Les ecclésiastiques, à partir de l'ordre de sous-diacre inclusivement, sont exempts du service militaire et des autres fonctions civiques incompatibles avec la vocation sacerdotale, comme par exemple: jurés, membres du tribunal, etc." = "Los eclesiásticos, a partir del orden del sub diaconado inclusive, están exentos del servicio militar y de otras funciones cívicas incompatibles con la vocación sacerdotal, como por ejemplo: jurados, miembros de tribunales, etc.", en: Enchiridion, p. 592, nº 1156.

${ }^{55}$ Concordat entre le Saint-Siège et le Gouvernement de Lettonie (30 mai 1922), art. $\mathrm{XV}$ : “L'immunité des églises, chapelles et cimitières será observée selon les normes du droit canon" = "La inmunidad de iglesias, capillas y cementerios será observada según las normas del derecho canónico”, ibíd., p. 594, n 1162.

${ }^{56}$ Sollemnis conventio inter Sanctam Sedem et Poloniae Rempublicam (10 februarii 1925), art. VI: "L'immunité des églises, des chapelles et des cimitières est assurée, sans que cependant la sécurité publique ait à en souffrir" = La inmunidad de iglesias, de capillas y de cementerios está asegurada, sin que, sin embargo, tenga que sufrir la seguridad pública”, ibíd., p. 656, nº 1288.

${ }^{57}$ Concordat entre le Saint-Siège et le Gouvernement de Lithuanie (27 septembre 1927), art. VI: “L'immunité des églises, des chapelles et des cimitières est assurée, sans que cependant la sécurité publique ait à en souffrir" = La inmunidad de iglesias, de capillas y de cementerios está asegurada, sin que, sin embargo, tenga que sufrir la seguridad pública", ibíd., p. 700, n 1392. 
concordatos. Nuevamente el modelo más cercano era el de Polonia, que es copiado textualmente por Lituania. El de Letonia era más favorable a la Iglesia toda vez que la inmunidad se aseguraba "según la norma del derecho canónico". Una amplitud semejante no parecía pensable en Chile. La frase "hasta donde lo permitan el respeto de la ley chilena", es una originalidad del proyecto chileno, que venía a reducir la ampliación que el artículo chileno hacía respecto de sus modelos, al haber incorporado los conventos entre los beneficiados con la inmunidad.

\subsection{Capellanes castrenses}

A los capellanes castrenses estaba dedicado el artículo 10, según el cual "El Ejército de Chile gozará de todas las exenciones que según las prescripciones del derecho canónico otorga la Santa Sede a otros ejércitos. Los capellanes castrenses, en su actuación referente a los militares y sus familias, tendrán los derechos inherentes a la cura de almas y ejercerán las funciones de su ministerio bajo la jurisdicción de un vicario general castrense que tendrá el derecho de escogerlos. En lo que se refiere al servicio militar este clero estará sometido a las autoridades militares". Nuevamente el modelo hemos de encontrarlo en el concordato con Polonia ${ }^{58}$, si bien en éste se entendía que el que los capellanes castrenses, en lo militar, estuvieren sometidos a las autoridades militares, era una

${ }^{58}$ Sollemnis conventio inter Sanctam Sedem et Poloniae Rempublicam (10 februarii 1925), art. VII: "Les armées de la Republique de Pologne jouiront de toutes les exemptions qui sont accordées aux armées par le Saint-Siège, selon les prescriptions du droit canonique. En particulier, les aumôniers auront, par rapport aux militaires et à leurs familles, les droits de curé et exerceront les fonctions de leur ministère sous la juridiction d'un Evêque d'Armée, qui aura le droit de les choisir. Le Saint-Siege permet que ce clergé, en ce qui concerne son service militaire, soit soumis aux autorités de l'Armée" = "Los ejércitos de la República de Polonia gozarán de todas las exenciones que son acordadas por la Santa Sede a los otros ejércitos, según las prescripciones del derecho canónico. En particular, los capellanes tendrán, en relación a los militares y a sus familias, los derechos de curato y ejercerán las funciones de su ministerio bajo la jurisdicción de un Obispo de Ejército, que tendrá el derechos de escogerlos. La Santa Sede permite que este clero, en lo que concierne a su servicio militar, esté sometido a las autoridades del Ejército", ibíd., pp. 656-658, nº 1289. 
concesión de la Santa Sede, a diferencia del proyecto chileno que lo otorgaba como una concesión unilateral. Como en los artículos anteriores, el concordato de Lituania sigue en esta materia al de Polonia, pero en un artículo más resumido ${ }^{59}$. Como en Chile existía ya el vicariato castrense al frente del cual se encontraba un vicario castrense ${ }^{60}$, el artículo chileno recogía esta realidad, pero, en lo demás, el modelo polaco es evidente. En todo caso, de nuevo se advierte en las autoridades chilenas su actitud de imponerse por sobre la Iglesia, pues el sometimiento de los capellanes a las autoridades militares en lo referido a lo militar, es ahora una decisión unilateral del Estado.

\subsection{Autoridad en Chile de obispos residentes fuera de Chile}

"Ninguna jurisdicción eclesiástica del territorio de Chile" disponía el artículo 12 "dependerá de un Obispo que tenga su residencia fuera de las fronteras de la República”. Seguía de cerca sus modelos polaco ${ }^{61} \mathrm{y}$ lituano ${ }^{62}$, materia que igualmente se encontraba en términos similares

${ }^{59}$ Concordat entre le Saint-Siège et le Gouvernement de Lithuanie (27 septembre 1927), art. VII: “Les armées de la République de Lithuanie jouiront de toutes les exemptions qui son accordées aux armées par le Saint-Siege selon les prescriptions $d u$ droit canon. Les aumoniers exerceront les fonctions de leur ministère sous la juridiction de l'archevêque, qui aura le droit de les choisir" = "Los ejércitos de la República de Lituania gozarán de todas las exenciones que son acordadas a los ejércitos por el derecho canónico. Los capellanes ejercerán las funciones de su ministerio bajo la jurisdicción de arzobispo que tendrá el derecho de escogerlos", ibíd., p. 700, n 1393.

${ }^{60}$ J.I. GonzÁlez ERrázuriz, Iglesia y Fuerzas Armadas. Estudio canónico y jurídico sobre la asistencia espiritual a las Fuerzas Armadas en Chile (Santiago de Chile, 1994).

${ }^{61}$ Sollemnis conventio inter Sanctam Sedem et Poloniae Rempublicam (10 februarii 1925), art. IX: “Aucune partie de la République de Pologne ne dépendra d'un evêque dont le siège se truverait en dehors des frontières de l'Etat polonais" = "Ninguna parte de la República de Polonia dependerá de un obispo cuya sede se encuentre fuera de las fronteras del Estado polaco". El artículo sigue describiendo la constitución de la jerarquía polaca, en: Enchiridion, p. 658, nº 1291.

${ }^{62}$ Concordat entre le Saint-Siège et le Gouvernement de Lithuanie (27 septembre 1927), art. IX: “Aucune partie de la République de Lithuanie ne dépendra d'un evêque dont le siège se truverait en dehors des frontières de l'Etat lithuanien" = "Ninguna parte de la República de Lituania dependerá de un obispo cuya sede se encuentre fuera de las fronteras del Estado lituano". El artículo, que es más extenso, sigue 
en el concordato con Rumanía ${ }^{63}$. Se trataba de una materia sensible a los Estados bálticos y danubianos, interesados, como estaban, de asegurar sus nuevas fronteras. Y se trataba también de una materia sensible para Chile, donde aún estaba vivo el tema de la jurisdicción eclesiástica del obispo peruano de Arequipa sobre los territorios del Norte de Chile, ocupados durante la Guerra del Pacífico ${ }^{64}$ y sometidos políticamente a las autoridades chilenas. De allí el interés por incorporar este artículo en el proyecto de concordato. Con todo, en el proyecto chileno, la palabra "territorio" era sustituida por "jurisdicción del territorio de Chile”, cambio que no parecía inocuo.

2.10. Superiores extranjeros de comunidades religiosas masculinas

El artículo 13 regulaba la creación de beneficios eclesiásticos y comunidades religiosas por parte de la autoridad eclesiástica competente, pero introducía algunas limitaciones. En efecto, "[inc. $1^{\circ}$ ] La creación

refiriéndose a la provincia eclesiástica cuyas diócesis y prelaturas fueron fijadas por la bula Lithuanorum gente, ibíd., p. 700, nº 1395.

${ }^{63}$ Inter Sanctan Sedem et Romaniae Regnum Sollemnis Conventio (10 mai 1927), art. III: "Aucune partie du Royaume de Roumanie ne dépendra d'un evêque dont le siège se truverait hors des frontières de l'Etat roumain; de même aucun diocèse de Roumanie no pourra s'étendre au-delà des frontierès du pays" = "Ninguna parte del Reino de Rumania dependerá de un obispo cuya sede se encuentre fuera de las fronteras del Estado rumano; de la misma manera ninguna diócesis de Rumanía podrá extenderse más allá de las fronteras del país", ibíd., p. 682, n 1339.

${ }^{64}$ La Guerra del Pacífico enfrentó a Chile con la confederación de Perú y Bolivia entre los años 1879 y 1883. Resultado de ella fue la ocupación, por parte de Chile, de los territorios peruanos de Tacna y Arica que quedaron sometidos politicamente a Chile, pero religiosamente al obispado peruano de Arequipa, cuyo obispo puso todo tipo de trabas a la tarea pastoral de los sacerdotes chilenos, razón por la que el gobierno de Chile solicitó a la Santa Sede el envío de sacerdotes extranjeros, a lo que se opuso el gobierno peruano y el obispo de Arequipa. La posterior expulsión de los sacerdotes peruanos de dicho territorio por parte del gobierno chileno dejó a la población peruana sin asistencia religiosa. La población chilena siguió teniéndola por medio del vicariato castrense, pues la mayoría de los chilenos residentes en dichas provincias fueron considerados auxiliares del ejército; pero los capellanes militares chilenos no podían atender a la población peruana aunque, como dicen las crónicas de la época, lo pedían con lágrimas en los ojos. 
o modificación de los beneficios eclesiásticos, y de las comunidades religiosas, como también de sus casas y establecimientos dependerá de las autoridades eclesiásticas competentes. [inc. $2^{\circ}$ ] Para el establecimiento en Chile de nuevas comunidades religiosas se requiere autorización del gobierno. [inc. $3^{\circ}$ ] Los extranjeros no podrán desempeñar los cargos de superiores de provincias de las comunidades religiosas de varones establecidas en Chile sin haber obtenido previamente autorización del gobierno". La exigencia de la propia nacionalidad para el desempeño de algunos oficios religiosos es una exigencia que, por lo general, estaba presente en los concordatos de la época, pero ella se refería más bien a los beneficios parroquiales, a los que también se va a referir el proyecto chileno en otro artículo. La limitación de nacionalidad para desempeñar oficios de gobierno en las comunidades religiosas era más excepcional, pero se encontraba en el concordato con Polonia $(1925)^{65}$ y en el modus vivendi con Checoslovaquia (1927) en el que se disponía que los superiores provinciales y de las casas religiosas que dependiesen directamente de las casas generalicias serían ciudadanos checoslovacos (art. III inc. $2^{\circ}$ ). El modelo polaco en esta parte del artículo chileno parece evidente.

\subsection{Juramento de los obispos}

Según el artículo 15, "Los ordinarios coadjutores con derecho de sucesión y el vicario general castrense, a que se refiere el art. 14, antes de asumir sus funciones, prestarán ante el presidente de la República el juramento siguiente: "Ante Dios y sobre los Santos Evangelios juro y prometo como obispo fidelidad a la República de Chile. Juro y prometo respetar con toda lealtad y hacer respetar por el clero de mi dependencia al gobierno establecido por la Constitución. Juro y prometo no

${ }^{65}$ Sollemnis conventio inter Sanctam Sedem et Poloniae Rempublicam (10 februarii 1925), art. X: "La création et la modification des bénéfices ecclésiastiques, des congrégations et ordres religieux, ansi que de leurs maisons et établissements, dépendra de l'autorité ecclésiastique compétente, laquelle, toutes les fois que les dites mesures entraînerait des dépenses pour le Trésor de l'Etat, y procédera après entente avec le gouvernement. Les étrangers no recevront pas la charge de supérieurs des provinces des ordres religieux, à moins d'avoir obtenu du gouvernement una autorisation à cet effet", en: Enchiridion, pp. 660, n. 1292. 
participar en ningún acuerdo o acción que pueda atentar contra Chile o el orden público, no permitiré a mi clero participar en semejantes actos, velaré por el bien y el interés del Estado y trataré de evitarle todo peligro que lo amenace". La fórmula que ofrecía este artículo seguía de cerca la que se estilaba por esos años en los concordatos contemporáneos en los que se contenía un juramento redactado en términos más o menos similares, como ocurría con Letonia $(1922)^{66}$, Polonia $(1925)^{67}$ que contenía una fórmula más extensa que el anterior,

${ }^{66}$ Concordat entre le Saint-Siège et le Gouvernement de Lettonie (30 mai 1922), art. V: “Avant d'entrer en fonctions, l'archevêque prêtera entre les mains du président de la Republique de Lettonie le serment de fidelité dans la forme suivante: «Je jure devant Dieu et sur les Saints Evangiles, comme il convient à un evêque, de respecter et faire respecter par le clergé le gouvernement établi par la Constitution de la République de Lettonie et de ne rien antreprendre qui soit de nature à compromettre l'ordre public»" = "Antes de entrar en funciones, el arzobispo prestará entre las manos del presidente de la República de Letonia el juramento de fidelidad en la forma siguiente: «Juro delante de Dios y sobre los Santos Evangelios, como conviene a un obispo, respetar y hacer respetar por los clérigos al gobierno establecido por la Constitución de la República de Letonia y de no emprender nada cuya naturaleza comprometa el orden público»", ibíd., p. 590, no 1150 .

${ }^{67}$ Sollemnis conventio inter Sanctam Sedem et Poloniae Rempublicam (10 februarii 1925), art. XII: "Les ordinaires ci-dessus [archevêques et evêques diocésains, les coadjuteurs cum iure succesionis, de même que l'evêque d'Armée], avant d'assumer leur fonctions, prêteront, entre les mains du président de la République, un serment de fidelité d'après la formule suivante: «Devant Dieu et sur les Saints Evengiles, je jure et je promets, comme il convient à un evêque, fidelitá à la République de Pologne. Je jure et je promets de respecter en toute loyauté et de faire respecter par mon clergé le gouvernement établi par la Constitution. Je jure et je promets en outre que je ne participerait à aucun accord ni n'assisterai à aucun conseil pouvant porter atteinte à l'Etat polonais ou à l'ordre public. Je ne permettrai pas à mon clergé de participer à de telles actions. Soucieux du bien et de l'intérêt de l'Etat, je tâcherai tout danger dont je le saurais menacé»" = "Los ordinarios anteriores, antes de asumir sus funciones, prestarán, entre las manos del presidente de la República, un juramento de fidelidad de acuerdo a la siguiente fórmula: "Ante Dios y sobre los Santos Evangelios, juro y prometo, como conviene a un obispo, fidelidad a la República de Polonia. Juro y prometo respetar con toda lealtad y de hacer respetar por mi clero al gobierno establecido por la Constitución. Juro y prometo además que no participaré en ningún acuerdo ni asistiré a ningún consejo que pueda ocasionar daño al Estado polaco o al orden público. No permitiré 
Rumania (1927) ${ }^{68}$, Lituania $(1927)^{69}$ y Checoslovaquia $(1927)^{70}$, cuya

a mi clero participar en tales acciones. Preocupado del bien y del interés del Estado, procuraré alejar todo peligro del que le sepa amenazado»", ibíd., p. 660, n 1294.

${ }^{68}$ Inter Sanctan Sedem et Romaniae Regnum Sollemnis Conventio (10 mai 1927), art. VI: "Les evêques, avant de prendre possession de leurs diocèses, prêteront serment selon la formule qui suit: "Devant Dieu et sur les Saints Evangiles, je jure et je promets fidélité à Sa Majesté le Roi de Roumanie ainsi qu'à ses successeurs, et, comme il convient à un évêque, de respecter et de faire respecter par mes sujets, avec la fidélité au Roi, la Constitution et les lois du pays. En outre je n'entreprendrai rien qui soit de nature à porter atteinte à l'ordre public où à l'integrité de l'Etat. Ainsi Dieu m'aide, et ces Saints Evangiles»" = "Los obispos antes de tomar posesión de sus diócesis, prestarán juramento según la fórmula que sigue: «Delante de Dios y sobre los Santos Evangelios, juro y prometo fidelidad a Su Majestad el Rey de Rumanía así como a sus sucesores, $y$, como conviene a un obispo, de respetar y hacer respetar por los sujetos a mí, con la fidelidad al Rey, la Constitución y las leyes del país. Además no emprenderé nada que sea de tal naturaleza que lleve a atentar contra el orden público o la integridad del Estado. Así Dios me ayude, y estos Santos Evangelios»", ibíd., p. 684, nº 1343 .

${ }^{69}$ Concordat entre le Saint-Siège et le Gouvernement de Lithuanie (27 septembre 1927), art. XII: "Les ordinaires ci-dessus [l'archevêque et evêques diocésains, les coadjuteurs cum iure succesionis], avant d'assumer leur fonctions, prêteront, entre les mains du président de la République, un serment de fidelité d'après la formule suivante: "Devant Dieu et sur les Saints Evengiles, je jure et je promets, comme il convient à un evêque, fidelité à la République de Lithuanie. Je jure et je promets de respecter en toute loyauté et de faire respecter par mon clergé le gouvernement établi par la Constitution. Je jure et je promets en outre que je ne participerait à aucun accord ni n'assisterai à aucun conseil pouvant porter atteinte à l'Etat lithuanien ou à l'ordre public. Je ne permettrai pas à mon clergé de participer à de telles actions. Soucieux du bien et de l'intérêt de l'Etat, je tâcherai tout danger dont je le saurais menacé»" = "Los ordinarios anteriores, antes de asumir sus funciones, prestarán, entre las manos del presidente de la República, un juramento de fidelidad de acuerdo a la siguiente fórmula: «Ante Dios y sobre los Santos Evangelios, juro y prometo, como conviene a un obispo, fidelidad a la República de Lituania. Juro y prometo respetar con toda lealtad y de hacer respetar por mi clero al gobierno establecido por la Constitución. Juro y prometo además que no participaré en ningún acuerdo ni asistiré a ningún consejo que pueda ocasionar daño al Estado lituano o al orden público. No permitiré a mi clero participar en tales acciones. Preocupado del bien y del interés del Estado, procuraré alejar todo peligro del que le sepa amenazado»", ibíd., p. 702, nº 1398.

${ }^{70}$ Modus vivendi inter Sanctam Sedem et Rempublicam Cecoslovacham (17 decembris 1927), art. V: “Les dignataires mentionnés dans l’article précedent, après la 
fórmula de juramento era la más breve de todas. De hecho, la fórmula propuesta por el gobierno de Chile seguía de cerca la fórmula inserta en el concordato con Polonia.

\subsection{Actos administrativos estatales sobre bienes eclesiásticos}

Disponía el artículo 17: "[inc. $1^{\circ}$ ] Los bienes pertenecientes a la Iglesia no serán sometidos a resoluciones o actos jurídicos que puedan modificar su destinación sin consentimiento de las autoridades eclesiásticas, salvo en los casos previstos en la ley respecto de expropiaciones por causa de utilidad pública. [inc. $2^{\circ}$ ] En estos casos la destinación de los inmuebles consagrados exclusivamente al culto divino, tales como las iglesias y sus dotaciones, será modificada una vez que la respectiva autoridad eclesiástica, notificada oportunamente, haya podido levantarles su carácter sagrado. [inc. $3^{\circ}$ ] No se procederá a ninguna construcción, modificación o restauración de iglesias o capillas sino conforme a las prescripciones del derecho común, que estén en vigencia con respecto a tales trabajos". El precedente inmediato de este artículo era el concordato con la República de Polonia, que en su artículo XIV ${ }^{71}$

nomination du Saint-Siege, avant d'assumer leurs fonctions, prêteront le serment de fidélité à l'Etát Tchécoslovaque par la formule suivante: «Iuro et promitto sicuti decet episcopum, fidelitatem Reipublicae Cecoslovachae necnon nihil me factorum quod sit contra salutem, securitatem, integritatem Reipublicae»" = "Los dignatarios mencionados en los artículos precedentes [obispos diocesanos, coadjutores con derecho de sucesión y ordinario del Ejército], después del nombramiento de la Santa Sede, antes de asumir sus funciones, prestarán el juramento de fidelidad al Estado Checoslovaco por la fórmula siguiente: "Juro y prometo como conviene a un obispo, fidelidad a la República Checoslovaca ni hacer nada que sea contra la conservación, la seguridad y la integridad de la República»", ibid., p. 714, nº 1428.

${ }^{71}$ Sollemnis conventio inter Sanctam Sedem et Poloniae Rempublicam (10 februarii 1925), art. XIV: “[inc. $1^{\circ}$ ] Les biens appartenant à l'Eglise ne seront soumis à aucun acte juridique, modifiant leur destination, sans le consentement des autorités ecclésiastiques, saufles cas prévus par les lois sur l'expropiation pour cause de systématisation des voies de transport et des rivières, de défense nationale et causes similaires. En tout cas la destination des immeubles et meubles, consacrés exclusivement au service divin, tels que les églises, les objets de culte, etc., ne pourra être modifiée sans que l'autorité ecclésiastique compétente les ait privés au préalable de leur caractère 
regulaba la misma materia en términos que el concordato chileno seguía de cerca, con las adecuaciones que ameritaba el cambio de realidades entre una y otra nación, como lo referido a la excepción de expropiación, que en el caso de Polonia, debía hacerse "por causa de arreglos de las vías de transporte y de ríos, de defensa nacional y casos similares", expresión que en el proyecto chileno se englobaba en "causa de utilidad pública". El concordato polaco, sin embargo, en este artículo regulaba tres situaciones diferentes, de las cuales el proyecto chileno recogió tan sólo dos, eliminando el inciso final del artículo polaco, que se refería a una realidad que en el Chile de los años 20 no merecía mucha atención, como es la de las “iglesias y locales eclesiásticos de la antigüedad, de las obras de arte, de los documentos de archivos y de manuscritos que posean un valor histórico y artístico". El concordato de Lituania (1927) que también siguió de cerca el de Polonia no recogió esta materia en su articulado. Tampoco regulaba

sacré. [inc. $2^{\circ}$ ] Aucune construction, modification ou restauration des églises et chapelles n'aura lieu qu'en accord avec les prescriptions techniques et artistiques des lois concernant la construction des batiments et la conservation des monuments. [inc. $3^{\circ}$ ] Dans chaque diocèse será formée une commission nommée par l'evêque, d'accord avec le ministre compétent, pour la conservation dans les églises et les locaux ecclésiastiques d'antiquités, d'oeuvres d'art, de documents d'archives et de manuscrits possédant une valeur historique au artistique" = "[inc. $1^{\circ}$ ] Los bienes pertenecientes a la Iglesia no serán sometidos a ningún acto jurídico, modificando su destinación, sin el consentimiento de las autoridades eclesiásticas, salvo los casos previstos por las leyes sobre expropiación por causa de arreglos de las vías de transporte y de ríos, de defensa nacional y causas similares. En todo caso la destinación de inmuebles y muebles, consagrados exclusivamente al servicio divino, tales como las iglesias, los objetos de culto etc., no podrá ser modificada sin que la autoridad eclesiástica competente los haya privado previamente de su carácter sagrado. [inc. $2^{\circ}$ ] Ninguna construcción, modificación o restauración de iglesias y capillas tendrá lugar sino de acuerdo con las prescripciones técnicas y artísticas de las leyes concernientes a la construcción de edificios y la conservación de monumentos. [inc. $3^{\circ}$ ] En cada diócesis será formada una comisión nombrada por el obispo con el ministro competente, para la conservación en las iglesias y los locales eclesiásticos de antigüedades, de obras de arte, de documentos de archivos y de manuscritos que posean un valor histórico o artístico", ibíd., p. 662, nº 1296. 
esta materia el concordato anterior con Letonia (1922) ni el celebrado con el reino de Rumanía (1925). El modelo polaco, así, es evidente.

\subsection{Adquisición de bienes por la Iglesia}

“Conforme a la legislación chilena", disponía el artículo 18, "las iglesias, los ordinarios, las parroquias y las comunidades religiosas legalmente establecidas en Chile estarán facultadas para adquirir, poseer, ceder y administrar, ciñéndose a las reglas del derecho canónico, sus bienes muebles e inmuebles, como también comparecer ante las autoridades del Estado en resguardo de sus derechos civiles". Introducía algunos cambios al artículo XVII del concordato con el gobierno de Lituania $^{72}$, al que seguía de cerca, el que, a su vez, se basaba en el artículo XVI del concordato con la República de Polonia ${ }^{73}$, modificaciones que

${ }^{72}$ Concordat entre le Saint-Siège et le Gouvernement de Lithuanie (27 septembre 1927), art. XVII: “Toutes les personnes juridiques ecclésiastiques et religieuses ont, selon les règles du droit commun, le droit d'acquérir, de céder, de posséder et d'administrer, conformément au droit canon, leurs biens meubles ou immeubles, de même que le droit d'ester devant toute instance au autorité de l'Etat pour la défense de leurs droits civils" = "Todas las personas jurídicas eclesiásticas y religiosas tienen, según las reglas del derecho común, el derecho de adquirir, de ceder, de poseer y de administrar, conforme al derecho canónico, sus bienes muebles o inmuebles, al igual que el derecho de comparecer antes toda instancia o autoridad del Estado para la defensa de sus derechos civiles", ibíd., p. 704, nº 1407.

${ }^{73}$ Sollemnis conventio inter Sanctam Sedem et Poloniae Rempublicam (10 februarii 1925), art. XVI: “Toutes les personnes juridiques ecclésiastiques et religieuses polonaises ont, selon les règles du droit commun, le droit d'acquérir, de céder, de posséder et d'administrer, conformément au droit canon, leurs biens meubles au immeubles, de même que le droit d'ester devant toute instance ou autorité de l'Etat por la défense de leurs droit civils. Les personnes juridiques ecclésiastiques et religieuses sont reconnus comme polonaises en tant que les fins pour lesquelles elles ont été établies concernent les affaires ecclésiastiques ou religieuses de la Pologne et que les personnes autorisées à las représenter et à administrer leurs biens, résident dans les territoires de la République de Pologne. Les personnes juridiques ecclésiastiques et religieuses, qui no répondraient pas aux conditions ci-dessus, jouiront des droits civiles accordés par la République aux étrangers" = "Todas las personas jurídicas eclesiásticas y religiosas polacas tienen, según las reglas del derecho común, el derecho de adquirir, de ceder, de poseer y de administrar, conforme al derecho canónico, sus bienes muebles e inmuebles, al igual 
se reducían a eliminar algunas expresiones utilizadas por el modelo lituano-polaco, por las dudas que suscitaban al momento de redactarse por las autoridades chilenas este artículo. En efecto, el proyecto chileno omitía toda referencia a la condición de persona jurídica de la Iglesia o de sus entidades, lo que, en cambio, hacían expresamente los concordatos polaco y lituano en los que, además de describirse las atribuciones que recogía el proyecto chileno, reconocía explícitamente la calidad de persona jurídica a lo que dichos concordatos denominaban "personas jurídicas eclesiásticas y religiosas". El proyecto chileno evitaba otorgar dicha calidad a la Iglesia y a sus entidades, no obstante que el Código Civil (1855, art. 547 inc. $2^{\circ}$ ) le otorgaba la calidad de personas jurídicas de derecho público a las "iglesias", esto es, a las diversas organizaciones que integraban la estructura jerárquica de la Iglesia, como eran los obispados o las parroquias, y a las "comunidades religiosas". La conservación o la pérdida de la personalidad jurídica de las iglesias y comunidades religiosas, al menos la personalidad jurídica de derecho público, era un tema que empezaba a debatirse en Chile en los años en los que se redacta este proyecto, por lo que las autoridades chilenas, con un criterio pragmático, optaron por obviar el tema de la personalidad jurídica de la Iglesia y de sus entidades, pero se la reconocieron de hecho al enumerar las facultades que ellas tenían, esto es, las de "adquirir, poseer, ceder y administrar”, ordenándolas de manera más lógica que en su modelo polaco.

\subsection{Cementerios católicos}

"Podrán administrarse en Chile los cementerios católicos existentes de acuerdo con la legislación chilena y el derecho canónico". Así

que el derecho de comparecer ante todas las instancias o autoridades del Estado para la defensa de sus derechos civiles. Las personas jurídicas eclesiásticas y religiosas son reconocidas como polacas en tanto que los fines para los cuales ellas han sido establecidas conciernan a los asuntos eclesiásticos o religiosos de Polonia y que las personas autorizadas a representarlas y a administrar sus bienes, residan en los territorios de la República de Polonia. Las personas jurídicas eclesiásticas o religiosas, que no respondan a las condiciones anteriores, gozarán de los derechos civiles acordados por la República a los extranjeros", ibíd., pp. 662, 664, n 1298. 
lo disponía el artículo 19 del proyecto, que abordaba el tema de los cementerios, que aparecía en el concordato con Polonia (1925), pero no era seguido en esto por el concordato con Lituania (1927) que guardaba silencio al respecto. El modelo, en consecuencia, era el concordato polaco, que trataba esta materia en el artículo XVII ${ }^{74}$, pero lo hacía en relación con "las personas jurídicas eclesiásticas y religiosas" sobre lo cual, como he señalado, el proyecto chileno guardaba silencio. Además, el concordato polaco especificaba que dichas personas "tienen el derecho de construir, de poseer y de administrar" cementerios, lo que el proyecto chileno reducía drásticamente, dejando una fórmula muy genérica que nada decía acerca de la propiedad de los mismos y del derecho a construirlos. En todo caso, a diferencia del modelo polaco, el proyecto chileno guardaba silencio en cuanto a que dichos cementerios fuesen para el enterramiento de los católicos, dejando la fórmula abierta también en este sentido.

El Código de Derecho Canónico (1917) vigente a la sazón, regulaba la materia de cementerios entre los cánones 1205 y 1214, uno de los cuales, el canon 1206 en su parágrafo primero afirmaba expresamente que "La Iglesia católica tiene derecho a poseer cementerios propios". Este artículo del proyecto venía a reconocer expresamente este derecho con una fórmula ambigua, que en parte quedaba salvada con la expresa referencia al derecho canónico.

\subsection{Fieles fuera de su diócesis}

"Los eclesiásticos y los fieles católicos que se encuentren fuera de su diócesis" diponía el artículo 20, "quedarán sometidos al ordinario local del punto donde se encuentren accidentalmente según las reglas del derecho canónico". Seguía de cerca el artículo XVIII del concordato

\footnotetext{
${ }^{74}$ Sollemnis conventio inter Sanctam Sedem et Poloniae Rempublicam (10 februarii 1925), art. XVII: "Les personnes juridiques ecclésiastiques et religieuses ont le droit d'établir, de posséder et d'administrer, selon le droit canon et d'accord avec le droit commun de l'Etat, des cimetières destinés à la sépulture des catholiques" = "Las personas jurídicas eclesiásticas y religiosas tienen el derecho de construir, de poseer $y$ de administrar, según el derecho canónico y de acuerdo con el derecho común del Estado, cementerios destinados a la sepultura de los católicos", ibíd., p. 664, n 1299.
} 
polaco $^{75}$, el único que contemplaba un artículo similar. Del modelo polaco se ha eliminado la referencia a los diversos ritos, realidad que no estaba presente en Chile, y se ha aclarado el artículo agregando que quedan sometidos al ordinario local "del punto donde se encuentren accidentalmente". Se trata de una materia estrictamente canónica que no interesa mayormente al Estado, regulada en los cánones 13 y 14 del Código de Derecho Canónico de 1917, por lo que no veo la utilidad de su regulación en un concordato. Es la razón por la que, en el margen del texto que he utilizado, que es el que se encuentra en el Archivo Secreto Vaticano y que, probablemente, ha sido el enviado por el nuncio al cardenal Secretario de Estado, aparece el signo de interrogación sobrescrito al margen del enunciado del artículo.

2.16. Obtención de beneficios parroquiales

Según el artículo 21, "Queda reconocido el derecho que asiste a las autoridades eclesiásticas competentes para proveer los beneficios, funciones y cargos eclesiásticos en conformidad al derecho canónico, pero en el territorio de Chile no podrán obtener beneficios parroquiales las personas que desarrollen actividades contrarias al orden público o a la seguridad del Estado, ni los extranjeros no nacionalizados, salvo, en el caso de estos últimos, que el gobierno diere autorización para el efecto". Tenía su origen el artículo XIX del concordato con Polonia ${ }^{76}$,

${ }^{75}$ Sollemnis conventio inter Sanctam Sedem et Poloniae Rempublicam (10 februarii 1925), art. XVIII: "Les ecclésiastiques et les fidèles de tous les rites, se trouvant hors de leur diocèses, seront soumis à l'ordinaire local selon les règles du droit canon" = "Los eclesiásticos y los fieles de todos los ritos, encontrándose fuera de sus diócesis, estarán sometidos al ordinario local según las reglas del derecho canónico”, ibíd., p. $664, \mathrm{n}^{\circ} 1300$.

${ }^{76}$ Sollemnis conventio inter Sanctam Sedem et Poloniae Rempublicam (10 februarii 1925), art. XIX: “[inc. 1] La République garantit le droit des autorités compétentes d'attribuer les fonctions, les charges et les bénéfices ecclésiastiques d'après les prescriptions du droit canon. A l'attribution des bénéfices paroissiaux seront appliquées les règles suivantes: [inc. $2^{\circ}$ ] Dans les territoires de la République de Pologne ne peuvent pas obtenir des bénéfices paroissiaux, à moins d'avoir reçu le consentement du gouvernement polonais: $1^{\circ}$ les étrangers non-naturalisés, ainsi que les persones dont l'éducation théologique n'a pas été faite dans les instituts théologiques de 
al que seguía de cerca el artículo XVIII del concordato con Litua-
nia $^{77}$, aunque la redacción del proyecto chileno resulta más sintética:

Pologne ou dans des institus pontificaux; $2^{\circ}$ les personnes dont l'activité est contraire à la sécurité de l'Etat. [inc. $3^{\circ}$ ] Avant de proceder aux nominations à ces benefices, l'autorité ecclesiastique s'informera auprès du ministre compétent de la République pour s'assurer qu'aucune des raisons, prévues ci-dessus aux points $1^{\circ}$ et $2^{\circ}$, ne s'y opposerait. Au cas où le ministre susmentionné ne présenterait pas, dans le délai de 30 jours de telles objections contre la personne dont la nomination est envisagée, la autorite ecclésiastique procédera à la nomitation" = "[inc. $1^{\circ}$ ] La República garantiza el derecho de las autoridades competentes para atribuir las funciones, los cargos y los beneficios eclesiásticos conforme a las prescripciones del derecho canónico. A la atribución de los beneficios parroquiales serán aplicadas las reglas siguientes: [inc. $2^{\circ}$ ] En los territorios de la República de Polonia no pueden obtener beneficios parroquiales, a menos de haber recibido el consentimiento del gobierno polaco: $1^{\circ}$ los extranjeros no naturalizados, así como las personas cuya educación teológica no ha sido hecha en los institutos teológicos de Polonia o en los institutos pontificios; $2^{\circ}$ las personas cuya actividad es contraria a la seguridad del Estado. [inc. $3^{\circ}$ ] Antes de proceder a los nombramientos en estos beneficios, la autoridad eclesiástica se informará cerca del ministro competente de la República para asegurarse que ninguna de las razones previstas arriba en los puntos $1^{\circ}$ y $2^{\circ}$ serán opuestas. En el caso que el ministro antes mencionado no presente, en el plazo de 30 días, tales objeciones contra la persona cuyo nombramiento es considerado, la autoridad eclesiástica procederá al nombramiento", ibíd., p. 664, n 1301.

${ }^{77}$ Concordat entre le Saint-Siège et le Gouvernement de Lithuanie (27 septembre 1927), art. XVIII: "[inc. 1] La République garantit le droit des autorités compétentes d'attribuer les fonctions, les charges et les bénéfices ecclésiastiques d'après les prescriptions du droit canon. A l'attribution des bénéfices paroissiaux seront appliquées les règles suivantes: [inc. $2^{\circ}$ ] Dans le territoire de la République de Lithuanie ne peuvent pas obtenir des bénéfices paroissiaux, à moins d'avoir reçu le consentement du gouvernement: $1^{\circ}$ les étrangers non-naturalisés; $2^{\circ}$ les personnes dont l'activité a été contraire à la sécurité de l'Etat. [inc. $3^{\circ}$ ] Avant de proceder aux nominations à ces benefices, l'autorité ecclesiastique s'informera auprès du ministre compétent de la République pour s'assurer qu'aucune des raisons, prévues ci-dessus aux points $1^{\circ}$ et $2^{\circ}$, ne s'y opposerait. Au cas où le ministre susmentionné ne présenterait pas, dans le délai de 30 jours de telles objections contre la personne dont la nomination est envisagée, la autorite ecclésiastique procédera à la nomitation" = "[inc. 1] La República garantiza el derecho de las autoridades competentes para atribuir las funciones, los cargos y los beneficios eclesiásticos conforme a las prescripciones del derecho canónico. A la atribución de los beneficios parroquiales serán aplicadas las 
los beneficios parroquiales sólo podían ser adquiridos por chilenos naturales o por extranjeros nacionalizados, salvo autorización del gobierno tratándose de extranjeros no nacionalizados; quedaban afuera, además, las personas que desarrollan actividades contrarias al orden público o la seguridad del Estado. El proyecto chileno dejaba fuera el inciso que, en sus modelos, establecía el procedimiento para la provisión de estos beneficios, con lo cual la forma de llevar a la práctica este artículo quedaba sin definir. Igualmente no acogía la objeción de estudios teológicos hechos fuera de Polonia salvo los institutos teológicos pontificios.

Como puede advertirse de la redacción de este artículo, por una parte el gobierno chileno reconocía "el derecho que asiste a las autoridades eclesiásticas competentes para proveer los beneficios, funciones y cargos eclesiásticos en conformidad al derecho canónico", pero inmediatamente limitaba dicho derecho en la forma señalada. Se trataba de una nueva expresión del neo-regalismo de las autoridades chilenas después de la separación Iglesia-Estado y recogía un artículo concordaticio que, si bien tenía su explicación en la realidad que estaba viviendo Polonia en esos años en los que acababa de obtener su independencia, no resultaba aplicable a la nueva realidad que estaba viviendo Chile, en que la Iglesia ya se había separado del Estado por voluntad del mismo Estado. El modelo polaco-lituano era la excusa que cubría de cierta legitimidad este artículo del proyecto chileno.

reglas siguientes: [inc. $2^{\circ}$ ] En los territorios de la República de Lituania no pueden obtener beneficios parroquiales, a menos de haber recibido el consentimiento del gobierno: $1^{\circ}$ los extranjeros no naturalizados; $2^{\circ}$ las personas cuya actividad ha sido contraria a la seguridad del Estado. [inc. $3^{\circ}$ ] Antes de proceder a los nombramientos en estos beneficios, la autoridad eclesiástica se informará cerca del ministro competente de la República para asegurarse que ninguna de las razones previstas arriba en los puntos $1^{\circ}$ y $2^{\circ}$ serán opuestas. En el caso que el ministro antes mencionado no presente, en el plazo de 30 días, tales objeciones contra la persona cuyo nombramiento es considerado, la autoridad eclesiástica procederá al nombramiento”, ibíd., pp. 704, $706, \mathrm{n}^{\circ} 1408$. 


\subsection{Acusaciones contra eclesiásticos}

Según el artículo 22, "Las autoridades de la República podrán formular acusaciones contra cualquier eclesiástico a causa de actividades contrarias al orden público o a la seguridad del Estado, en demanda de medidas eclesiásticas contra él. Estas acusaciones se presentarán al ordinario respectivo, el cual las considerará y resolverá, tomando las medidas adecuadas en el menor plazo posible. Si se produjere desacuerdo, lo resolverá una comisión compuesta de dos eclesiásticos nombrados por la Santa Sede y dos delegados nombrados por el gobierno". Se basaba una vez más en el concordato con Polonia, en concreto su artículo $\mathrm{XX}^{78}$. Una norma similar no se encontraba en el concordato lituano, aunque también se basó en el de Polonia. En el proyecto chileno, sin embargo, si bien se recogían las actividades contrarias "a la seguridad del Estado", como lo hacía el modelo polaco, se agregaban las actividades contrarias "al orden público". Además, la cláusula chilena matizaba un poco la intervención gubernamental, pues, a diferencia del concordato polaco que establecía que las medidas del ordinario han de tomarse "de acuerdo" con el ministro denunciante, en el caso chileno se dejaba al ordinario que tomare las medidas que estimare "adecuadas" sin intervención del gobierno. En todo caso, como el gobierno podía estar en desacuerdo con las medidas adoptadas, si es

\footnotetext{
${ }^{78}$ Sollemnis conventio inter Sanctam Sedem et Poloniae Rempublicam (10 februarii 1925), art. XX: “Au cas où les autorités de la République auraient à soulever contre un ecclésiastique des objections au sujet de son activité comme contraire à la securité de l'Etat, le ministre compétent présentera les dites objections à l'ordinaire qui, d'accord avec ce ministre, prendra dans les trois mois les mesures appropriées. Au cas d'une divergence entre l'ordinaire et le ministre, le Saint-Siege confiera la solution de la question à deux ecclésiastiques de son choix, lesquels, en accord avec deux délégués du président de la République, prendront une décision définitive" = "En caso de que las autoridades de la República tuvieren que levantar contra un eclesiástico objeciones a propósito de su actividad como contraria a la seguridad del Estado, el ministro competente presentará dichas objeciones al ordinario que, de acuerdo con este ministro, tomará en tres meses les medidas apropiadas. En caso de una divergencia entre el ordinario y el ministro, la Santa Sede confiará la solución de la cuestión a dos eclesiásticos de su elección, los cuales, en acuerdo con dos delegados del presidente de la República, tomarán una decisión definitiva”, ibíd., p. 664, nº 1302.
} 
que se adoptaba alguna, se establecía la misma comisión que en el concordato polaco.

El artículo 22 se refería a acusaciones contra eclesiásticos hechas ante su ordinario. El artículo siguiente, en cambio, se colocaba en el supuesto de acusaciones contra eclesiásticos ante los tribunales del Estado por delitos comunes. En efecto, según el artículo 23, "Si algún eclesiástico o religioso fuere acusado ante los tribunales chilenos por crímenes previstos en las leyes penales de la República, el tribunal respectivo informará sin pérdida de tiempo al ordinario correspondiente y le trasmitirá el auto de acusación y, en su oportunidad, la sentencia con sus considerandos".

Nuevamente la norma modelo era la del concordato polaco en cuyo artículo $\mathrm{XXII}^{79}$ se había inspirado este artículo del proyecto chileno

${ }^{79}$ Sollemnis conventio inter Sanctam Sedem et Poloniae Rempublicam (10 februarii 1925), art. XXII: "[inc. $1^{\circ}$ ] Si des ecclésiastiques ou religieux sont accusés près des tribunaux lä̈ques de crimes prévus par les lois pénales de la République, ces tribunaux informeront immédiatement l'ordinaire compétent de chaque affaire de ce genre et lui transmettront, le cas échéant, l'acte d'accusation et l'arrêt judiciaire avec ses considérants. L'ordinaire, ou son délégué, auront le droit, après conclusions de la procédure judiciaire, de prendre connaissance des dossiers relatifs. Dans le cas d'arrestation ou d'emprisonnement des personnes susmentionnées, les autorités civiles procéderont avec les égards dus à leur état et à leur rang hiérarchique. [inc. $2^{\circ}$ ] Les ecclésiastiques et religieux seront détenus et subiront les peines de réclusion dans des locaux séparés des locaux destinés aux laïques, à moins d'avoir été privés par l'ordinaire compétent de leur dignité d'ecclésiastiques. Au cas où ils seraient condamnés par jugement à la détention, ils subiront cette peine dans un couvent ou otre maison religieuse, en des locaux destinés à cet effet" = "[inc. 1'] Si eclesiásticos o religiosos son acusados ante tribunales laicos por crímenes previstos por las leyes penales de la República, estos tribunales informarán inmediatamente al ordinario competente de cada asunto de este género y le transmitirán, llegado el caso, el acta de acusación y la sentencia judicial con sus considerandos. El ordinario, o su delegado, tendrán el derecho, después de la conclusión del proceso judicial, de tomar conocimiento del expediente relativo. En el caso de arresto o prisión de las personas mencionadas, las autoridades civiles procederán con las consideraciones debidas a su estado y a su rango jerárquico. [inc. $2^{\circ}$ ] Los eclesiásticos y religiosos serán detenidos y sufrirán las penas de reclusión en locales separados de los locales destinados a los laicos, a menos de haber sido privados por el ordinario competente de su dignidad 
y el artículo que seguía. Así, lo que en el concordato con la República de Polonia era un solo artículo, en el proyecto chileno se había convertido en dos artículos diversos, pero íntimamente relacionados. El concordato con Lituania (1927) repetía casi en los mismos términos en su artículo $\mathrm{XX}^{80}$, la cláusula polaca, reproduciendo en un solo artículo lo que en el proyecto chileno se regulaba en dos artículos.

El artículo 22 chileno recogía una actuación de cortesía hacia las autoridades eclesiásticas cuando los tribunales del Estado, actuando dentro de sus competencias, procedían a procesar a un eclesiástico

eclesiástica. En el caso que sean condenados por sentencia, ellos sufrirán esta pena en un convento u otra casa religiosa, en locales destinados a este efecto", ibíd, p. 666, $\mathrm{n}^{\circ} 1304$.

${ }^{80}$ Concordat entre le Saint-Siège et le Gouvernement de Lithuanie (27 septembre 1927), art. XX: "[inc. 1] Si des ecclésiastiques ou religieux sont accusés près des tribunaux lä̈ques de crimes prévus par les lois pénales de la République, ces tribunaux informeront immédiatement l'ordinaire compétent de chaque affaire de ce genre et lui transmettront, le cas échéant, l'acte d'accusation et l'arrêt judiciaire avec ses considérants. L'ordinaire, ou son délégué, auront le droit, après conclusions de la procédure judiciaire, de prendre connaissance des dossiers relatifs. Dans le cas d'arrestation ou d'emprisonnement des personnes susmentionnées, les autorités civiles procéderont avec les égards dus à leur état et à leur rang hiérarchique. [inc. $2^{\circ}$ ] Les ecclésiastiques et religieux seront détenus et subiront la peine de réclusion dans des locaux séparés des locaux destinés aux lä̈ques, à moins d'avoir été privés par l'Ordinaire compétent de leur dignité d'ecclésiastiques. Au cas où ils seraient condamnés par jugement à la détention, ils subiront cette peine dans un couvent ou otre maison religieuse, en des locaux destinés à cet effet" = "[inc. $1^{\circ}$ ] Si eclesiásticos o religiosos son acusados ante tribunales laicos por crímenes previstos por las leyes penales de la República, estos tribunales informarán inmediatamente al ordinario competente de cada asunto de este género y le transmitirán, llegado el caso, el acta de acusación y la sentencia judicial con sus considerandos. El ordinario, o su delegado, tendrán el derecho, después de la conclusión del proceso judicial, de tomar conocimiento del expediente relativo. En el caso de arresto o prisión de las personas mencionadas, las autoridades civiles procederán con las consideraciones debidas a su estado y a su rango jerárquico. [inc. $2^{\circ}$ ] Los eclesiásticos y religiosos serán detenidos y sufrirán la pena de reclusión en locales separados de los locales destinados a los laicos, a menos de haber sido privados por el ordinario competente de su dignidad eclesiástica. En el caso que sean condenados por sentencia, ellos sufrirán esta pena en un convento u otra casa religiosa, en locales destinados a este efecto", ibíd., p. 706, n 1410. 
o religioso por crímenes previsto en las leyes penales de la República. Un artículo similar se encontraba en el concordato con Letonia $(1922)^{81}$, si bien la facultad que se daba a la autoridad eclesiástica era diversa, en atención a la modalidad procesal usada en dicha nación.

Por su parte, el artículo 24 contenía una norma respetuosa para con los clérigos delincuentes, cuando eran sometidos a prisión, pues "En caso de arresto o de prisión de un eclesiástico o religioso, las autoridades civiles procederán con todas las consideraciones debidas a su carácter o rango eclesiástico, $y$, en cuanto lo permitan las condiciones y el régimen del establecimiento penal en que debiere ingresar, se le señalará local de reclusión separado, a menos que el ordinario competente lo haya privado de la dignidad eclesiástica". Como en los artículos anteriores, su origen se encontraba en el paso final del inciso $1^{\circ}$ y en el inciso $2^{\circ}$ del artículo XXII del concordato con Polonia $(1925)^{82}$ y en los mismos incisos del artículo XX del concordato con Lituania $(1927)^{83}$ que hacía suyo en los mismos términos el artículo XXII polaco. Lo que las normas polaca y lituana redactaban en un solo artículo, en el proyecto chileno se desdoblaba en dos. Un artículo similar se encontraba también en el concordato con Letonia $(1922)^{84}$, pero, si bien la idea era la misma, la redacción del proyecto chileno

${ }^{81}$ Concordat entre le Saint-Siège et le Gouvernement de Lettonie (30 mai 1922), art. XVIII: "Si des ecclésiastiques sont accusés près des tribunaux läques de crimes prévus par le Code de Lettonie, l'archevêque ou son délégué será en temps opportun avisé et lui, ou son délégué, pourra assister aux séances des tribunaux et aux débats du proces" = "Si eclesiásticos son acusados ante los tribunales laicos de crímenes previstos por el Código de Letonia, el arzobispo o su delegado será avisado en tiempo oportuno y él, o su delegado, podrá asistir a las sesiones del tribunal y a los debates del proceso", ibíd., p. 594, nº 1165.

${ }^{82}$ Véase antes nota 79.

${ }^{83}$ Véase antes nota 80.

${ }^{84}$ Concordat entre le Saint-Siège et le Gouvernement de Lettonie (30 mai 1922), art. XIX: "Les ecléssiastiques condamnés par jugement à la detention subiront leur peine d'arrêt dans un monastère. Dans les autres cas, les ecclésiastiques coupables subiront leur peine, comme les autres condamnés, après que l'archevêque les aura privés de la dignité ecclésiastique" = "Los eclesiásticos condenados por sentencia a prisión sufrirán su pena de detención en un monasterio. En los otros casos, los eclesiásticos 
seguía más de cerca al concordato polaco; de hecho, a diferencia del proyecto chileno, según el concordato letón el eclesiástico detenido debía sufrir la detención en un monasterio. Aun en estos detalles se advertía el afán del gobierno chileno de mantener el control sobre lo eclesiástico, pues la detención debía de hacerse en los lugares que el Estado de Chile disponía al efecto, no en lugares eclesiásticos.

\section{Conclusiones}

Llegados al final de esta páginas, podemos resumirlas en las siguientes conclusiones:

$1^{\circ}$ Terminada la primera Guerra Mundial se va a iniciar para la Santa Sede una intensa actividad concordataria, siendo uno de los primeros concordatos firmados durante el pontificado de Pío XI, el concordato con Polonia (1925) que sirvió de modelo al que, poco después, se firmó con Lituania (1927).

$2^{\circ}$ Cuatro meses después de la firma del concordato con Lituania, presentó sus credenciales ante el gobierno de Chile el nuncio Ettore Felici, quien, siguiendo instrucciones que había recibido a su partida desde Roma, de inmediato inició gestiones para lograr que Chile llegara a un acuerdo similar con la Santa Sede. Para ello, le entregó un ejemplar del concordato que, tres meses antes, había celebrado la Santa Sede con Lituania, concordato que, a su vez, seguía de cerca el que, en 1925, había celebrado la Santa Sede con Polonia.

$3^{\circ}$ Los dos proyectos redactados por el gobierno chileno se inspiran de cerca en el concordato lituano entregado por el nuncio. Pero es claro que, además, tomaron como modelo el concordato de 1925 con Polonia que, con seguridad, fue enviado por el embajador de Chile ante la Santa Sede. Un simple cotejo textual permite ver que, en no pocas ocasiones, la redacción de los artículos chilenos se aproxima más al modelo polaco que al lituano.

$4^{\circ}$ Transcurridos más de 80 años de las gestiones hechas en 1928 para firmar un concordato entre Chile y la Santa Sede, no existe aún

culpables sufrirán su pena, como los otros condenados, después que el arzobispo les haya privado de la dignidad eclesiástica”, en Enchiridion, p. 594, nº 1166. 
un concordato o acuerdo entre ambos poderes soberanos. Se trata, pues, de una materia pendiente. Como parte de las materias que en esos proyectos se regulaban siguen siendo de interés para Chile y la Santa Sede, dichos proyectos pueden servir como punto de partida para lo que podría ser un futuro acuerdo antre ambas altas partes. Si así fuera, el concordato de Polonia de 1925 todavía seguiría inspirando, a través de los proyectos chilenos de 1928, un acuerdo que entonces no pudo ser pero que, quizá, en un futuro próximo, pueda ser.

\section{The concordat between the Holy See and Poland in 1925 as the source for the projects for a concordat between Chile and the Holy See in 1928}

Due to the separation of the Church and the Chilean State, as stated by the Constitution of 1925, conversations took place, in order to celebrate a concordat between the Chilean State and the Holy See, without any concrete knowledge of projects aimed at this end. The opening of the Vatican Secret Archive, with reference to the funds of Pope Pius XI's pontificate has enabled the knowledge of drafts written in 1928 by the Chilean Government with the intention of reaching an international agreement on such matter. These Chilean drafts used as a model the concordats that earlier had been agreed by the Holy See with Lithuania (1927), and Poland (1925), including various dispositions that followed closely the norms of the Polish concordat. The Chilean projects for a concordat written in 1928, and the influence on the articles exerted by the Polish concordat of 1925 are herein presented and analyzed.

Palabras clave: Concordato, Iglesia, Estado en Chile, concordato con Polonia (1925), concordato con Lituania (1927), proyectos chilenos de concordato (1928).

Key Words: Concordat, Church, Chilean State, Concordat with Poland (1925), Concordat with Lithuania (1927), Chilean projects for a concordat (1928).

Nota o Autorze:

Prof. Carlos Salinas Araneda - Catedrático de Historia del Derecho y Derecho Canónico en la Pontificia Universidad Católica de Valparaíso, Chile. Profesor, History of Law and Canon Law. 